\title{
Immunobiology of Allograft Human Leukocyte Antigens in the New Microenvironment
}

\author{
Mepur H. Ravindranath*, Vadim Jucaud, Paul I. Terasaki \\ Terasaki Foundation Laboratory, 11570 W, Olympic Blvd, Los Angeles, CA 90064, California, USA
}

Received: August 19, 2015; Accepted: August 28, 2015; Published: October 21, 2015

*Corresponding author: Mepur H. Ravindranath, Terasaki Foundation Laboratory, 11570 W. Olympic Blvd, Los Angeles, CA 90064, USA, Tel: +310-479-6101 ext. 103; Fax: +310-445-3381; E-mail: ravimh@terasakilab.org

\begin{abstract}
Absract
The antibodies formed by allograft recipients against donors' mismatched allo-human leukocyte antigens (allo-HLA) correlate with graft rejection. This review's aim is to elucidate the immunological events associated with allografts' mismatched HLA from transplantation to acute/chronic rejection. Such clarification may permit more precisely relevant therapeutic strategies that can facilitate better graft survival. The trigger event in the allograft microenvironment is an inflammatory response, promoting overexpression of allo-HLA as dimers or monomers. Overexpression of membrane- bound HLA is accompanied by matrix membrane proteases that dissociate and release monomeric HLA from the cell surface, forming soluble HLA (sHLA), and the recipient's immune components interacting with both membrane-bound and sHLA. Immune recognition of allo-HLA may vary depending on whether the allo-HLA is dimeric or monomeric. An important player in immune rejection of the allograft appears to be sHLA.
\end{abstract}

Monomeric sHLA that are free of $\beta 2$-microglobulin $(\beta 2 \mathrm{~m})$ bind to receptors of allogenic cytotoxic T cells (NKT and CD8+ T cells) to prevent cytolytic destruction of the allograft, and they expose epitopes that $\beta 2 \mathrm{~m}$ made cryptic. The antibodies formed against donor-specific allo-sHLA during acute/chronic rejection cause arteriosclerosis and affect the glomerular filtration rate, leading to allograft rejection. Anti-HLA antibodies can be diverse, some recognizing specific epitopes on the mismatched allo-HLA, others recognizing the cryptic but common shared epitopes $\beta 2 \mathrm{~m}$ previously masked. When monoclonal antibodies to sHLA were generated, it was shown that the functions of monospecific antibodies differ from those of polyreactive antibodies, which recognize epitopes shared with all HLA-I alleles and suppress T-cell proliferation while monospecific antibodies can induce proliferation of CD8+ T cells. Knowing the physicochemical structure of HLA-I/-II is essential for the elucidation of HLA functions. Although the functional potentials of $\mathrm{N}$-linked carbohydrates located at the junction of the antigen-presenting groove remain unexplored anti-HLA antibodies are monitored by coating recombinant HLA (rHLA) on solid matrices. The coated rHLA are not glycosylated nor is the ratio of monomeric and dimeric rHLA constant for all alleles. This review emphasizes that until these issues are resolved, we cannot comprehend why several allograft recipients do not show any signs of pathogenicity or rejection episodes post-transplantation in spite of the presence of donor specific allo-HLA Abs.

Keywords: Allograft; Alloreactive; Arteriosclerosis; Creatinine; Donor organ; Endothelial cells; Glomeruli; Glycosylresidues; Microenvironment; Monoclonal antibodies (mAbs); Monospecific mAbs; N-linked carbohydrates; Polyreactive mAbs; Proinflammatory cytokines; Recipient; Rejection; Vasculitis; Viremia

\section{Abbreviations}

$\beta 2 \mathrm{~m}$ : $\beta 2$-Microglobulin; $\beta 2 \mathrm{~m}$-free HC: $\beta 2 \mathrm{~m}$-free Heavy Chain; CTL: CD8+ Cytotoxic T Lymphocytes; DSA: Donor Specific Antibodies; HC: Heavy Chain Polypeptide; HLA: Human Leukocyte Antigens; HLA-I: Human Leukocyte Antigen Class I; HLA-II: Human Leukocyte Antigen Class II; IFN $\gamma$ : Interferon- $\gamma$; kDa: kilodalton; MHC: Major Histocompatibility Complex; MMP: Matrix Metalloproteinase; rHLA: Recombinant HLA; sHLA: soluble HLA

\section{Introduction}

The biological process involved in transplantation is comparable to the ecological concept of "habitat selection." When an organism is exposed to a challenging new environment, survival of the organism depends on a sequence of events: initial shock response, acclimation, adaptation, and, finally, survival: not being rejected or killed. Survival of the transplanted organ in the new host depends on the same sequence of events: initial shock response to inflammation caused by infiltration of inflammatory cells, immune reactions similar to those of hypersensitivity type IV with or without infection, then acclimation (equivalent to tolerance and avoidance of acute rejection), and, finally, adaptation if the allograft is not rejected by the microenvironment of the new host. A comprehensive understanding of the events taking place in the allograft microenvironment is necessary in order to develop strategies to prevent allograft rejection. Several factors are involved in this microenvironment such as augmentation of cell-mediated and antibody-mediated immune responses against allograft-associated antigens, and, even today, our understanding of the sequential events in the immune response is poor or incomplete. That information, however, it is very much needed to render the microenvironment congenial to allograft survival, facilitating allograft acceptance in the new environment; and an understanding of the changes occurring in the allograft microenvironment soon after transplantation is essential. There is also a need to elucidate the all components in the allograft microenvironment, whether natural (like cellular elements, molecules or even pathogens introduced or pre-existing in the microenvironment) or clinically imposed (exogenous components such as immunosuppressive agents 
and other molecules). This review focuses on only one aspect of the initial shock response: the major cellular component (or antigen) known as the Major Histocompatibility Complex (MHC). This complex is expressed by the tissues of the allograft, and is altered under the influence of the new microenvironment. The alteration includes monomerization (e.g., $2 \mathrm{~m}$-free HLA-I) and both overexpression and activation of the enzymes (matrix membrane proteinases) that cleave membrane-bound HLA-these being the primary symptoms of shock response to the altered profiles of the new microenvironment. The new host environment then responds to the allograft's HLA by eliciting immune-cell infiltration and augmentation of proinflammatory cytokines. The allograft responds to the new environment by releasing the cell surface allo-HLA into the host microenvironment. The shed alloHLA interacts with proinflammatory allo-immune cells, resulting in suppression of cytotoxic CD8+ T and NK cells and upregulation of CD4+ T cells and B cells, culminating in the production of antibodies. This interaction between the allograft and the microenvironment is on-going. Monitoring the sequence of events associated with the shock response is critical for developing appropriate treatment strategies and for realizing the possibility of organ-specific therapies pre- and post-transplantation.

The MHC is a group of cell-surface molecules encoded by a large gene family that controls a major part of human immunobiology. MHC molecules interact with several kinds of immune cells; they possess the critical determinants of the compatibility of donors for organ transplant. The MHC gene family is divided into three subgroups: classes I, II, and III. Class I MHC molecules have $\beta 2$ subunits; hence can be recognized only by CD8 co-receptors. Class II molecules have no $\beta 2$ subunits so can be recognized by CD 4 co-receptors. In humans, the MHC classes I and II are also known as the Human Leukocyte Antigens (HLA). The third region (located between the other two) encodes for MHC class III, the other important proteins involved in the immune system such as $\mathrm{CBF}, \mathrm{C} 2$, and C4A complement genes, a group of Tumor Necrosis Factors (TNF), and heat shock protein 70 chaperoning genes. The list of the many additional genes includes peptide transporter proteins TAP1 and TAP2, and PSMB8 and PSMB9 genes that code for components of the $\beta$-immuno-proteasome.

\section{The HLA system: First thesis}

HLA constitute the centerpiece of the immunobiology of transplantation. Jon van Rood first identified what would later be designated "HLA-Bw4 and -Bw6," and he published (with van Leeuwen) "Leukocyte grouping: A method and its application" in 1963 [1]. Two important clinical studies elucidated the relevance of leukocyte grouping in understanding transplant immunology. The first was also by van Rood (with Eernisse and van Leeuwen) [2], involving platelet transfusion. Eernisse gave the first platelet transfusion; it was from an unknown blood donor to a pregnant woman who had developed severe aplastic anemia after chloramphenicol treatment. This patient stopped bleeding after random platelet transfusions, but had developed anti-human leukocyte antibodies, possibly generated against the donor platelets. When platelet recovery dropped to zero, her bleeding recommenced. During this period, nine genetically determined leukocyte groups or HLA were recognized, which prompted verification of whether the patient's eight brothers and sisters had what the authors called a "negative leukocyte agglutination cross match" with the patient's serum. This turned out to be the case; so, every week, one of these siblings donated platelets to their sister, resulting in an excellent recovery.

The second important study was that of Terasaki, et al. [3], presented at the Conference on Histocompatibility testing in Washington, DC, in 1964. After extensive investigations between 1959 and 1961 of antibody responses to homografts [4-10], Paul Terasaki, in collaboration with pioneering renal transplant surgeon, Thomas Starzl, showed that the allo-HLA antibodies pre-existent in a recipient are responsible for the rejection of kidney allografts. This was the first and conclusive proof of the role of allo-HLA antibodies in allograft rejection. Concurrently, Jean Dausset and his team in a Paris blood bank found "humoral antibodies after skin homografting"-as reported at the $6^{\text {th }}$ International Transplantation Conference in New York [11]. After examining the allo-HLA antibodies formed in longterm kidney transplant survivors, Terasaki, et al. [3], highlighted the importance of HLA testing in transplantation, stressing the need for testing HLA groups or types both in donors and organ recipients. This study marked the beginning of the humoral theory of rejection in transplantation.

\section{Elucidation of donor-specific HLA antibodies: Terasaki's humoral theory}

The Dausset team had examined anti-HLA antibodies using a "Leuko-agglutination" assay [12]; but soon, Terasaki and his team began to develop [13,14], validate [15-17] and finally establish [18-21] a more sensitive assay to monitor the alloantibodies to HLA that are directly involved in the rejection of organs by allograft recipients. Terasaki postulated the humoral theory of organ rejection [22] and developed strategies for indepth characterization of antibodies formed against HLA specific to the donor organ-i.e., Donor-Specific Antibodies (DSA) [23]. Elucidating the nature of DSA required chemical characterization of the structure and diversity of HLA. These efforts helped bring about a better understanding of the specificity of auto-HLA antibodies, naturally occurring allo-HLA antibodies and DSA.

A persisting enigma is that even though DSA may exist in HLA-mismatched allograft recipients, not all recipients reject the transplant. What does this mean? Could two different categories of DSA exist-pathogenic and non-pathogenic DSA? If so, how can transplant immunologists or clinicians distinguish them? For this, an in-depth knowledge of the variability of the molecular structure, chemistry and specificity of donor HLA and the nature and diversity of antibodies formed against them is critical.

The current concepts concerning DSA have evolved with the discovery of Donor-Specific (DS) soluble HLA in allograft recipients and the evolution of assays employed in monitoring both HLA and their antibodies. Understanding the structural diversity of HLA class I and II expressed on the membrane, their diversity in different cell populations, and the diversity of those 
released from the membrane into the internal environment (extracellular domain, circulation or body fluids) is important for elucidation of the immune responses to HLA in general and particularly in transplantation.

\section{Diversity of HLA groups}

Ever since van Rood's "Leukocyte grouping" thesis, efforts to clarify the allelic diversity of HLA continued. Recognition of diverse human leukocyte groups led to in-depth analyses of HLA alleles, significantly increasing understanding of the nature and diversity of HLA. The naming of new HLA genes and allele sequences and their quality control has been effected since 1968 by the World Health Organization's Nomenclature Committee for Factors of the HLA System, which meets regularly, and has published several reports documenting HLA, their genes and alleles. The standardization of HLA antigenic specifications is controlled by the exchange of typing reagents and cells at the International Histocompatibility Workshops. The international immunogenetics project (http://www.ebi.ac.uk; or http://www.ebi.ac.uk/ipd/imgt/hla/intro.html) updated HLA genes and alleles in July 2015 [24].

In humans, the HLA genes are located in the short arm of chromosome 6 (6p21.3), which is composed of three regions. The first is the distal region, containing the genome of MHC class I, which includes the classical (Ia) HLA molecules-HLA-A, -B, and $-C$ heavy chains with extensive polymorphis-3,192 alleles at HLA-A; 3,977 at HLA-B; and 2,740 at HLA-C loci (Table 1)-and the non-classical (Ib) HLA- E, -F, and -G. HLA-I is expressed on the surface of nearly all nucleated cells. All HLA-I molecules form heterodimers with $\beta 2$ - microglobulin $(\beta 2 \mathrm{~m})$ coded by a gene on chromosome 15. In addition, the distal region contains the MHC class I chain-related MICA and MICB. The second region is the proximal (closer to the centromere), containing genes for two heavy chains of MHC class II, consisting of HLA-DR,-DQ, -DP, -DM, and -DO (for known alleles and proteins see Table 1). HLA-II molecules are expressed on Antigen-Presenting Cells (APC) such as macrophages, dendritic cells, Langerhans and Kuepfer cells, as well as B lymphocytes. Almost every cell in the body expresses HLA-II upon inflammation-most notably, thyroid epithelial cells, intestinal epithelial cells and endothelial cells. The third region (located between the other two) encodes for MHC Class III, which includes other important immune system proteins such as $\mathrm{CBF}$, $\mathrm{C} 2$, and C4A complement genes, a group of Tumor Necrosis Factors (TNF), and heat shock protein 70 chaperoning genes. The list of the many additional genes includes peptide transporter proteins TAP1 and TAP2, and PSMB8 and PSMB9 genes that code for components of the $\beta$-immuno-proteasome.

Each person carries a pair of chromosomes 6 and therefore expresses on the surface of a single cell one or two HLA-I alleles, each, for HLA-A, HLA-B and HLA-C, several HLA-1b, and one to four HLA-II alleles, each, of HLA-DR, -DQ, and -DP, all together comprising hundreds of thousands of different units [24]. Since each person carries a unique set of HLA genes, the array of possible combinations expressed by each individual in a given population is enormous. This HLA diversity-along with the multiplicity of alleles- leads to the extraordinary individuality and potential diversity in antigen presentation.

Given the enormous diversity of HLA types and combinations, it is very difficult to find unrelated individuals who are identical. Information on the specific HLA types of the donor and recipient is required to match the HLA types of the allograft with the recipient's HLA types. The tests available to identify HLA type range from low-resolution, serological typing, to high-resolution, more specific molecular typing. Tissues in the donor organ may be of HLA types totally different from those of recipient's tissues; or the ratio of matched and mismatched HLA types between

Table 1: Numbers of HLA Alleles (as of July 2015) and their proteins.

\begin{tabular}{|c|c|c|c|c|c|c|}
\hline \multicolumn{7}{|c|}{ HLA Class I } \\
\hline Gene & A & B & C & $\mathbf{E}$ & $\mathbf{F}$ & G \\
\hline Alleles & 3,192 & 3,977 & 2,740 & 17 & 22 & 50 \\
\hline Proteins & 2,245 & 2,938 & 1,941 & 6 & 4 & 16 \\
\hline \multicolumn{7}{|c|}{ HLA Class II } \\
\hline Gene & DRA & DRB & DQA1 & DQB1 & DPA1 & DPB1 \\
\hline Alleles & 7 & 1,868 & 54 & 807 & 40 & 550 \\
\hline Proteins & 2 & 1,364 & 32 & 539 & 20 & 447 \\
\hline \multicolumn{7}{|c|}{ HLA Class II - DRB Alleles } \\
\hline Gene & DRB1 & DRB2 & DRB3 & DRB4 & DRB5 & DRB6 \\
\hline Alleles & 1,764 & 1 & 59 & 16 & 21 & 3 \\
\hline Proteins & 1,290 & 0 & 47 & 9 & 18 & 0 \\
\hline \multicolumn{7}{|c|}{ Other non-HLA Genes } \\
\hline Gene & MICA & MICB & TAP1 & TAP2 & & \\
\hline Alleles & 102 & 41 & 12 & 12 & & \\
\hline Proteins & 80 & 27 & 6 & 5 & & \\
\hline
\end{tabular}




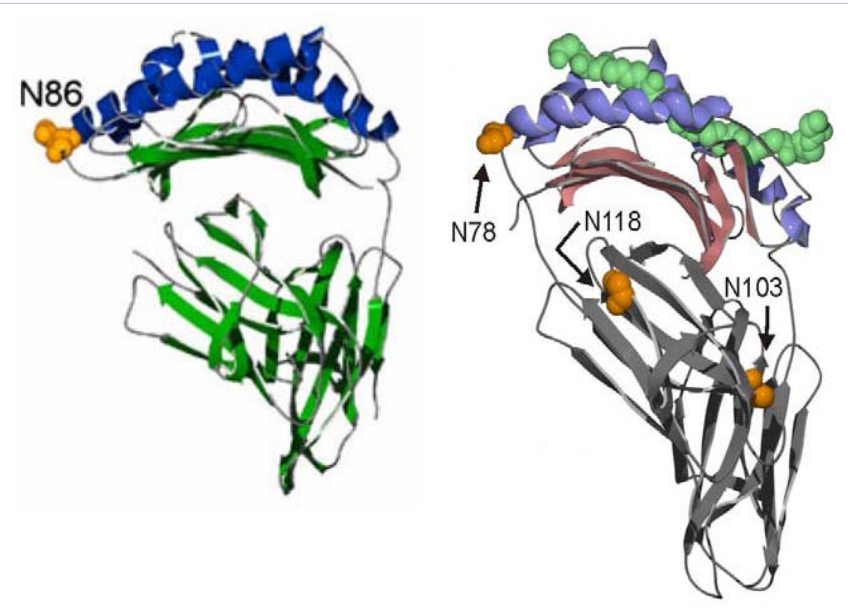

Figure 1: The lateral views of HLA class I (left) and class II (right) molecules. The antigen binding groove ( $\alpha$ helices) are blue. Sites of N-glycan sites are orange. Source; Ryan SO and Cobb BA, [25] and Ryan, et al. [30].

donor and recipient may vary in degree. Not all HLA allele types are considered in matching(e.g., HLA-Cw, DP, and HLA-Ib). Our review of the immunobiology of allograft HLA in the new environment addresses the extent to which matching of donor and recipient HLA types is needed for graft survival in that host microenvironment.

\section{Structural diversity of HLA on the cell surface}

Understanding cell-surface expression of HLA is key to elucidation of the interaction of HLA with other cells, their receptors, and different kinds of antibodies that may lead to cell survival and proliferation-or to cell death. The expression of each HLA molecule may differ depending on the cell type, physiological status of the cells, and status after shedding from the cell surface into the internal environment. Though it is well known that both HLA class I and II molecules are glycoproteins, the glycosylation of HLA has received the least attention of all factors affecting transplant immunobiology. The true definition of native HLA is a glycosylated $\alpha$-helical protein. Ryan and Cobb provided an excellent review of the structure and functions of HLA glycosylation in HLA immunobiology [25].

\section{Cell-surface HLA diversity caused by glycosylation}

Glycosylation patterns in HLA-I and HLA-II: In general with glycoproteins, two kinds of carbohydrate moieties are attached to amino acids: An asparagine-linked (N-linked) oligosaccharide chain of about $3 \mathrm{kDa}$ and a serine-linked (O-linked) oligosaccharide. In HLA-I molecules, only the N-linked oligosaccharides are common whereas in HLA-II molecules both $\mathrm{N}$ - and $\mathrm{O}$-linked (serine/threonine) oligosaccharides may occur. The extracellular region carries a single $\mathrm{N}$-linked oligosaccharide composed of residues of $\mathrm{N}$-acetylglucosamine, mannose, galactose, fucose and sialic acid [26]. One must realize that these complex $\mathrm{N}$-glycans are large and highly flexible structures extending to $30 \AA$, roughly corresponding to the size of an immunoglobulin domain $[27,28]$. Most important, HLA-I has a single carbohydrate moiety at asparagine $(\mathrm{N})$ position 86 from the NH-terminal end of the $\alpha 1$ domain of the heavy chain, whereas HLA-II has three known glycosylation sites (based on HLA-DR2) on both the $\alpha$ and $\beta$ chains: N78, N118, and N103 [29,30] (Figure $1)$. It is clear from these studies that the structural conformation of HLA- crucial for receptor or antibody recognition- may differ depending on the glycosylation of the HLA molecules [31-33].

Glycosylation of a particular HLA molecule may differ with the cell types within an individual: In normal cells, HLA-I molecules are principally fucosylated biantennary structures while HLA-DR class-II molecules have bi-, tri- and tetraantennary structures and high-mannose structures. The sugar residues on a single HLA allele or molecule may differ with cell type within a person [34,35]. For example, the level of sialylation (addition of the number and possibly the nature of sialic acids) of HLAII molecules may differ between normal B cells and normal monocytes, with the level higher in B cells than in monocytes. The pattern of glycosylation of the same HLA in the B-cell line transformed by an Epstein-Barr virus (EBV) is very different from that of the native B cells: the biantennary structures are decreased concomitant with an increase of the tri- and tetraantennary structure fractions-especially in HLA-II molecules-while both triantennary and high-mannose structures are increased in HLA-I molecules. Moreover, when compared with normal B cells, HLA-I molecules in the EBV-transformed B-cell line are under-sialylated, and HLA-II over-sialylated. It is possible that viremia of the donor or the recipient can induce changes in HLA glycosylation patterns. For example, the inflammation caused by human CMV, a common virus found in both donors and recipients, is capable of stimulating HLA-I transcription and can significantly enhance and alter the expression of HLA-I [36].

It is important to note that the pattern of glycosylation of HLA on the surface of malignant human cancer cells may differ markedly from that of its non-malignant counterpart [37]. Perhaps even more significant, alterations in cellular protein glycosylation have been reported in inflammatory bowel disease and patients with colon cancer [38,39]. It is also well documented that gastric epithelial cells show varied glycosylation of HLA-II compared with B cells [40] at inflamed sites. These observations raise a concern about whether glycosylation of a particular HLA-I or -II allele in the endothelial cells of a donor organ can differ from that of the recipient's cells.

Functions of the glycosylation residues in HLA: The glycosyl residues on glycoproteins serve as a check point for proper protein folding and trafficking to the cell surface [31-33]; they also protect the protein backbone from proteolysis once it is on the cell surface [41] and promote the appropriate geometric spacing of receptors and other molecules on the cell surface for optimized cell-cell attachment and communication with the immune components of the host [42].

Ryan, et al. [30] demonstrated that the presence of the carbohydrate moiety on HLA-II is essential for presentation of a certain class of peptides. In contrast to native glycosylated HLA-DR2, recombinant (bacterially expressed) DR2 failed to 
associate with peptides containing sugar residues (also known as glycoantigens or GlyAg) despite being properly folded and fully capable of binding to antigenic peptide. Similarly, elimination of native complex $\mathrm{N}$-linked glycans (i.e., unaltered mammalian complex N-glycans) on HLA-II reduced the presentation of some peptides in live APC, nearly eliminated their binding to recombinant HLA-II in vitro, and significantly limited in vitro and in vivo GlyAg-mediated T-cell recognition and activation despite no detectable defects in peptide and intact protein antigen controls. These findings established the importance of glycosyl residues on HLA-II in the modulation of antigen binding and presentation and this study marked the first time that the $\mathrm{N}$-linked glycans on HLA class II was shown to be integral to antigen binding.

Glycosylation residues can affect antibody recognition of HLA: Monitoring donor-specific HLA antibodies posttransplantation is an essential early step in clinical evaluation, and several tools are available for that monitoring including both an enzyme-linked immunoassay that uses microtiter plates and Luminex single antigen bead assay. HLA-I and HLA-II reactivity of allograft recipients' IgG is analyzed and the data acquired by Single Antigen Bead assay using dual-laser flow cytometry with Luminex XMAP ${ }^{\circledR}$ multiplex technology $\left(\right.$ LABScan $^{\text {mo }} 100$; One Lambda, Inc., Canoga Park, CA). More than 95\% of published studies of HLA antibodies in transplantation used Luminex single antigen beads, and it is important to note not only that the beads are coated with recombinant HLA but also that none of the HLA molecules are glycosylated. So the operative factors in monitoring anti-HLA antibodies are aglycosylated recombinant HLA molecules. Frequently in the literature, these aglycosylated HLA are wrongly thought to be native HLA. Clinicians deduce the existence of DSA based on the reactivity of IgG antibodies to what is usually called the "aglycosylated version" of allo-HLA coated on the beads. Even when present, though, these DSA often do not lead to graft rejection. That is possibly due to the fact that these antibodies may bind to aglycosylated allo-HLA but not to glycosylated HLA in the native state. If the antibody binds to an epitope located near the glycosylation site, then the antibody may bind to beads but not to the native HLA. This possibility impels the need to verify whether the DSA that bind to aglycosylated HLA on beads also bind to glycosylated HLA. As long as the HLA coated on the beads are not glycosylated, true assessment of DSA cannot make.

When the beads (or solid matrix) are coated with aglycosylated recombinant HLA, the coating is a mixture of heavy chains (HC) with $\beta 2$-microglobulin $(\beta 2 \mathrm{~m})$. Therefore, each bead may contain both dimeric and monomeric HLA molecules representing a single HLA allele. However, published reports infer that the antibodies bind to native HLA. Certainly, the $2 \mathrm{~m}$-associated recombinant HLA-I on the beads do mimic the physical conformation of the native HLA with $\beta 2 \mathrm{~m}$; however it is unknown what percentage of recombinant HLA-I is with or without $\beta 2 \mathrm{~m}$ on the beads. Recently One Lambda introduced "i-beads" to eliminate $\beta 2 \mathrm{~m}$-free heavy chains to monitor $\beta 2 \mathrm{~m}$-associated HLA. In spite of this useful effort, the ratio of $\beta 2 \mathrm{~m}$-free and $\beta 2 \mathrm{~m}$-associated heavy chains of HLA-I is not resolved and therefore there is no certainty as to whether the anti-HLA antibodies bind to $\beta 2 \mathrm{~m}$-free and $\beta 2 \mathrm{~m}$ associated heavy chains of HLA.

In any case, early investigators were influenced by the observation of Ploegh, et al. [43] that neither the lack of carbohydrate nor the presence of glycosylation affects reactivity with human alloantisera or the mouse monoclonal Antibody $(\mathrm{mAb}) \mathrm{W6} / 32$ that reacts with all HLA-A and -B specificities. The hybridoma-secreting mAb W6/32 (IgG2a) was established by immunizing a mouse with membrane from human thymocyte preparations [44]. The purified form of $\mathrm{mAb}$ was used to confirm that the mAb recognizes HLA-A, -B and - $\mathrm{Cw}$ alleles when they are associated with $\beta 2 \mathrm{~m}$, but not when they are free from $\beta 2 \mathrm{~m}$ [45]. $\beta 2 \mathrm{~m}$-free HLA are recognized by the mAb HC10 and also by Q1/28 [46-49]. It is of interest that neither the lack of carbohydrate nor the presence of glycosylation affected the binding affinity of these mAbs (W6/32, HC10 and HCA2), which were extensively used to immunolocalize HLA-I. Obviously, these antibodies bind to a sequence of amino acids far from the single glycosylation site $\left(\mathrm{Asn}^{86}\right)$ in HLA-I. Similar binding was also observed with some of the polyclonal antibodies in human serum [25] although patients' polyclonal anti-HLA sera cannot be restricted only to these antibodies.

Based on these and similar findings, it became dogma that glycosyl residues on the HLA-I molecule do not interfere with antibody recognition of HLA, making it acceptable to define anti-HLA antibodies and DSA by screening the antibodies with solid matrices coated with aglycosylated recombinant HLA molecules. This generalization was also extended to serum antiHLA antibodies for allograft recipients. From the therapeutic perspective, there exists a possibility that some antibodies in humans, although binding to beads coated with aglycosylated HLA, may not bind to glycosylated native HLA, accounting for the observed fact that, in spite of the presence of such DSA, rejection does not always occur. It is important to visualize the difference in size: the glycoslation residue, which is located near the gate of one end of the peptide groove, is about $30 \AA$, while the diameter of the peptide groove is $12-16 \AA$.

In this regard, the work of Ferrone's group [50] is significant. By employing a diagnostic $\mathrm{mAb}(\mathrm{Q} 6 / 64)$, they demonstrated that the glycosylation of the HLA-I HC can hinder antibody recognition either directly or by altering the conformation of the $\alpha 1$ helix. There is a need to identify and characterize the mAbs that can distinguish glycosylated from non-glycosylated HC of HLA-I and -II molecules. It should be established whether an antibody that recognizes a native HLA allele on the cell surface can also recognize HLA in their true native state in the presence of glycosylation or aglycosylated HLA. Until that is done, the HLA antibodies claimed to be "HLA-allele-specific" or "donorHLA-allele-specific" will remain enigmatic. Such antibodies may account for allograft survival in spite of the presence of a high level of DS HLA antibodies [51].

\section{Cell-surface HLA diversity caused by the absence of $\beta 2$ - microglobulin}

Another important component of HLA-I immunobiology, 
highly relevant to transplantation, is the naturally occurring $\beta 2 \mathrm{~m}$-free HC of HLA that has immunomodulary potential. To understand the microenvironment of the allograft and how immune responses (both cellular and humoral) are generated against the HLA of the allograft, it is important to recognize and accept the natural existence of $\beta 2 \mathrm{~m}$-free HC of HLA molecules both on the cell surface and in body fluids. There is often the misconception in the literature that $\beta 2 \mathrm{~m}$-free HC of HLA is "denatured HLA". In fact, the recombinant (deglycosylated) HLA-I molecules coated onto solid matrix or microbeads-with or without coupling to $\beta 2 \mathrm{~m}$-are the true denatured molecules of HLA-I since natural $\beta 2 \mathrm{~m}$-free HLA-I is glycosylated as is $\beta 2 \mathrm{~m}$-associated HLA-I. Recent better understanding about the proinflammatory cytokine-mediated upregulating of $\beta 2 \mathrm{~m}$-free HLA-I and potential novel immunoregulatory functions of $\beta 2 \mathrm{~m}$ free HLA-I elevates those molecules to a pedestal when it comes to understanding the immunobiology of transplantation and the significant role $\beta 2 \mathrm{~m}$-free HLA-I plays in a variety of immune functions. The following section validates the immunological potential of $\beta 2 \mathrm{~m}$-free HCs of HLA.

\section{W6/32-negative, anti-H serum-positive HLA-I}

The anti-HLA mAb W6/32 is a valuable tool for identifying the HLA-I dimer-the HC, both glycosylated and non-glycosylated, associated with $\beta 2 \mathrm{~m}$. While studying the biosynthesis of HLA-I molecules in the human B lymphoblastoid cell line T5-1, which is positive for HLA-Al, -A2, -B8, and -B27, Strominger's group noted the failure of $W 6 / 32$ to recognize $\beta 2 \mathrm{~m}$-free HLA [52] They also noticed that anti-H polyclonal serum, which failed to recognize $\beta 2 \mathrm{~m}$-associated HLA, did recognize $\beta 2 \mathrm{~m}$-free HLA. Based on their immunostaining and immunoprecipitation with W6/32 and anti- $\mathrm{H}^{2}$, they confirmed the presence of two distinct populations of HLA HCs. W6/32 recognized the HC population associated with $\beta 2 \mathrm{~m}$ while anti-H specifically precipitated the HLA molecules devoid of $\beta 2 \mathrm{~m}$. The group reported that "W6/32 reactive material was detected on the cell surface, whereas anti-H-reactive material ... could only sometimes be detected in small quantities on overexposed fluorographs. Thus, at most only 1 or $2 \%$ of the heavy chains present on the surface of T5-1 were precipitable by anti-H" [52]. Since this report, cell-surface expression of $\beta 2 \mathrm{~m}$-free HLA-Ihas received considerable attention; some investigators have even speculated that $\beta 2 \mathrm{~m}$-free $\mathrm{HC}$ could be immunologically inert [53]. In any case, expression of $\beta 2 \mathrm{~m}$ free HCs is observed across lymphocyte subpopulations (CD3+ T cells, CD19+ B cells, CD56+ NK cells and CD14+ monocytes), and-most important-these HCs are overexpressed particularly on activated cells and on extravillous trophoblast and monocytes [54].

\section{Can $\beta 2 \mathrm{~m}$-free HC hold and present peptides-as does intact HLA-I?}

When HLA-I is assembled in the endoplasmic reticulum and exported to the cell surface, a peptide of appropriate length and sequence is incorporated with $\beta 2 \mathrm{~m}$-associated HC. Peptide binding to the groove on the $\alpha 1$ and $\alpha 2$ helices of HLA-I results in the formation of a stable heterotrimer from an unstable $\beta 2 \mathrm{~m}$-associated HC heterodimer. Such a conformational change provides a strong interaction between the three components and also signals the release of stably assembled HLA-I molecules from the endoplasmic reticulum. Very little is known about the peptide-carrying capabilities of $\beta 2 \mathrm{~m}$-free HC of HLA-I. Rigney, et al. [55] studied the peptide-induced conformational change in $\mathrm{HC}$ that lacked $\beta 2 \mathrm{~m}$ : they added synthetic peptides to cell lysates containing $2 \mathrm{~m}$-free HC of HLA-I. Based on the pattern of conformational changes, the physiological relevance is implicated. The Rigney group demonstrated that the synthetic peptides, binding the $\beta 2 \mathrm{~m}$-free platform, is relatively stable in physiological buffers and undergoes a conformational change that is detectable with antibodies. Most important, they showed that the structural features of peptides that induce this conformational change in the platform are the same as those required to observe the conformational change in $\beta 2 \mathrm{~m}$-associated HC. These observations confirm that the $\alpha 1$ and $\alpha 2$ domains of $\beta 2 \mathrm{~m}$-free HC-which together form the peptide binding site of class I MHC-are able to act independent of the rest of the molecule. Springer, et al. showed that the $\alpha 1$ and $\alpha 2$ domains of HC devoid of $\beta 2 \mathrm{~m}$ can remain stable and peptide-receptive as long as they are glycosylated [56]. Despite this, the group could not obtain the crystalline structure of the peptide carrying $\alpha 1$ and $\alpha 2$ domains of $\mathrm{HC}$ devoid of $\beta 2 \mathrm{~m}$ nor could they successfully perform these experiments on a membrane matrix carrying $\beta 2 \mathrm{~m}$-free $\mathrm{HC}$ [57].

\section{Immunological relevance of $\beta 2 \mathrm{~m}$-free $\mathrm{HC}$}

The first evidence for the immunological relevance of $\beta 2 \mathrm{~m}$ free HC was provided by Schnable, et al. [58] when they observed that $\mathrm{T}$ lymphocytes, activated in vitro or in vivo, but not resting, expressed a considerable number of surface $\beta 2 \mathrm{~m}$-free HLA-I HC molecules. While W6/32 recognized the $\beta 2 \mathrm{~m}$-associated HC of HLA-I, the mAbs L45 and HC10 bound specifically to $\beta 2 \mathrm{~m}$ free-but not to $\beta 2 \mathrm{~m}$-associated-HC of HLA-I. W6/32 did not bind to $\beta 2 \mathrm{~m}$-free HLA-I. Immunoprecipitation and co-capping experiments showed that LA45 bound to $\beta 2 \mathrm{~m}$-free HLA-I HC at the cell surface. It is interesting that $\mathrm{L} 45$ bound to PHA-activated $\mathrm{T}$ cells from a panel of 12 people with different HLA types, suggesting that LA45 may bind to epitopes shared by all HLA-I HCs. The $\beta 2 \mathrm{~m}$-free HLA-I molecules expressed on the cell surface of activated T cells-or EBV-transformed B cells-are referred to as "peptide-binding empty HLA" [59,60].

\section{Immunologic potential of $\beta 2 \mathrm{~m}$-free $\mathrm{HC}$ as "open conformer"}

The expression of $\beta 2 \mathrm{~m}$-free HLA class I HC was confirmed on activated T cells in vitro and in vivo as well as on B cell lines (RAJI, NALM6), EBV-transformed B cells, and the myeloid cell line KG-1A $[58,61,62]$. The expression of $\beta 2 m$-free HLA observed on the cell surface in normal human $\mathrm{T}$ cells upon activation and cell division was found to be proportional to the level of proliferation [63]. Biochemical analysis showed that the $\beta 2 \mathrm{~m}$-free HCs (called "open conformers") present at the cell surface are fully glycosylated [63]. $\beta 2 \mathrm{~m}$-free HCs are tyrosine phosphorylated and are associated with kinase activity. The investigators showed that inhibition of tyrosine phosphorylation with the Src-family 
tyrosine kinase inhibitor PP2 resulted in enhanced release of $\beta 2 \mathrm{~m}$-free HCs from the cell surface of activated T cells. A review of the literature on open conformers suggests that, as one report put it, the function of the open MHC-I conformers seems to be related to their inherent ability to cis-associate, both with themselves and with other receptors [64]. Data indicate that the open MHC-I conformers are regulators of ligand-receptor interactions and have potential implications for immune activation.

\section{"Self"- and receptor-associating immunopotential of B2m-free HC}

In comparison with healthy control tissues, inflamed tissues (such as in spondylo-arthorpathy) show increased levels of $\beta 2 \mathrm{~m}$ free HCon CD14b+ monocytes compared with other leukocyte subsets. The level of $\beta 2 \mathrm{~m}$-free $\mathrm{HC}$ is also increased on activated dendritic cells on the extravillous trophoblast [54]. The unusual properties of the $\beta 2 \mathrm{~m}$-free $\mathrm{HC}$ of the B27 allele include an ability of this $\beta 2 \mathrm{~m}$-free $\mathrm{HC}$ to maintain the peptide binding groove in vitro [65]. $\beta 2 \mathrm{~m}$-free HC of HLA-B27 may induce arthritis in transgenic mice. It is interesting that $\beta 2 \mathrm{~m}$-free HC-specific antibodies decreased the disease incidence in this model [66]. $\beta 2 \mathrm{~m}$-free HCs exist as dimers or in clusters at the cell surface in vivo [65,67-70], which could have profound effects on receptor engagement.

HLA class I molecules are also known as ligands for members of the killer Ig receptor family (KIR) and Ig-like transcript (ILT)/LIR/LILR family (the new LILR nomenclature is at www. genenames.org/genefamilies/LIiLR ). Members of these families bound HLA-B27 in both $\beta 2 \mathrm{~m}$-associated and $\beta 2 \mathrm{~m}$-free HC. HLA-B27 HC with $\beta 2 \mathrm{~m}$ bound ILT2, ILT4, and LIR6 transfectants but not ILT1, ILT3, or ILT5. $\beta 2 \mathrm{~m}$-free HC of HLA-B27 bound ILT4 and LIR6. HLA-B27 $\beta 2 \mathrm{~m}$-free HC bound CD14 cells in peripheral blood lymphocytes from healthy controls, which was consistent with ILT4 expression on monocytes. Alternative recognition of $\beta 2 \mathrm{~m}$-associated and $\beta 2 \mathrm{~m}$-free HCs HLA-B27 by KIR or ILT could influence their immunomodulatory function and may imply a role in inflammatory disease [71].

\section{Role of $\beta 2 \mathrm{~m}$-free $\mathrm{HC}$ in antibody-mediated signal transduction}

Two important aspects of $\beta 2 \mathrm{~m}$-free HLA have emerged from the observations. First, on the cell surface, these molecules are capable of reacting with "self" to form homodimers. Matko, et al. [69] made it clear that $\beta 2 \mathrm{~m}$-free HLA molecules are capable of clustering upon overexpression on the surfaces of activated and transformed human cells. Second, $\beta 2 \mathrm{~m}$-free HLA can interact with other cell-surface receptors on the activated lymphocytes. On the cell surface of activated lymphocytes, not only are $\beta 2 \mathrm{~m}$-free HLA upregulated but so are IL-2R [72-74], Fc receptors for IgG (Fc $\gamma \mathrm{RI} /$ CD64, Fc $\gamma$ RII/CD32 and Fc $\gamma$ RIII/CD16) [75], IgE (FceRII)/CD23) [76], insulin receptors, insulin-like growth factors $1 \mathrm{R}$ and IL-2R [77], alpha-fetoprotein and transferrin receptors [78], a nondisulphide-linked heterodimer of polypeptide chains $33 \mathrm{kDa}$ and $38 \mathrm{kDa}$ called "Me14/D12" [79], MICA [80], and, finally, HLA class II antigens HLA-DR, -DP and -DQ [81-83].
Investigation at the Terasaki Foundation Laboratory found that different regions of $\beta 2 \mathrm{~m}$-free HLA can be recognized independently by various epitope-specific mAbs. We have identified two such domains, one comprising peptide sequences of $\alpha 1 \& \alpha 2$ helices $\left({ }^{65}\right.$ RSARDTA $^{71}$ and ${ }^{143}$ SEQKSNDASE $\left.{ }^{152}\right)$ and another peptide sequence that remains cryptic in the presence of $\beta 2 \mathrm{~m}$ but is exposed upon loss or absence of $\beta 2 \mathrm{~m}$ and is shared with other HLA class I molecules $\left({ }^{117}\right.$ AYDGKDYLT $^{125}$, ${ }^{126}$ LNEDLRSWTA $^{135}$ ] [84-88,89-91].

While studying the specificity of anti-HLA-E antibodiesboth commercial and generated in-house-the Terasaki group observed several anti-HLA-E antibodies that are not specific for HLA-E. Although generated by immunizing recombinant $\beta 2 \mathrm{~m}$-free HLA-E, they bound to all HLA-I molecules coated onto microbeads, which were monitored on a Luminex platform. Two of these anti-HLA-E mAbs (TFL-006 and TFL-007) bound to HLA-A, $-\mathrm{B},-\mathrm{Cw},-\mathrm{F}$ and $-\mathrm{G}[84,85]$, and these polyreactive mAbs recognized peptide sequences shared by all HLA classI molecules [86-88].What is most important, both TFL-006 and TFL-007 suppressed secretion of anti-HLA antibodies by activated B cells [92] and also the blastogenesis and proliferation of activated CD4+ T lymphocytes [93]. It was postulated that TFL-006 and TFL-007 were able to bind to the shared epitopes in $\beta 2 \mathrm{~m}$-free HLA, which were previously hidden in the presence of $\beta 2 \mathrm{~m}$-associatedHLA. This in turn signaled T-cell deactivation leading to suppression of blastogenesis and proliferation. A signal-transducing function of the cytoplasmic tail is implicated because, in contrast to $\beta 2 \mathrm{~m}$-associated HC, $\beta 2 \mathrm{~m}$-free HLA molecules, overexpressed on activated $\mathrm{T}$ lymphocytes, have an elongated cytoplasmic tail (the consequence of exon 6 and 7) with phosphorylation sites (tyrosine and serine at, respectively, positions 320 and 335) [9496].

In contrast to their TFL-006 and TFL-007-which recognize amino acid sequences shared by almost all $\beta 2 \mathrm{~m}$-free HLA molecules but are masked by $\beta 2 \mathrm{~m}$ in $\beta 2 \mathrm{~m}$-associated HLAthe Terasaki group [89] also generated mAbs (TFL-033, TFL034, TFL-073 TFL-074, and TFL-145)that specifically recognize HLA-E, but do not bind HLA-A, -B, - $\mathrm{Cw},-\mathrm{F}$ or $-\mathrm{G}$. The group designated these "HLA-E monospecific mAbs," and, using $\mathrm{mAb}$ TFL-033, they confirmed the expression of HLA-E on gastric cancer cells [90]. They also noted that these monospecific mAbs are specifically capable of inducing CD8+ cytotoxic T cells with or without co-stimulation. This induction of proliferation of resting CD8+ T cells by the monospecific anti-HLA-E mAbs-which bind to $\alpha 1$ and/or $\alpha 2$ helices expressed by HLA-E-specific amino acid sequences, resulting in a further five-fold increase in the induction of proliferation of PHA-activated CD8+T cells-suggests that the phosphorylation of the tyrosyl and serine residues of the elongated cytoplasmic tail of HLA-E open conformers may be involved in signal transduction. Open conformers are situated on the lipid raft of the bi-layered lipid membrane of non-phosphorylated non-activated CD8+ $\mathrm{T}$ cells. Binding of monospecific anti-HLA-E mAbs to the HLA-E open conformers may induce Lymphocyte-Specific Protein Tyrosine Kinase (LCK) to phosphorylate the tyrosyl residue located on the cytoplasmic 
tail of HLA-E. The enhanced proliferation of PHA-activated CD8+ $\mathrm{T}$ cells could be due to clustering of $\beta 2 \mathrm{~m}$-free HLA molecules on the cell surface as documented by Matko and colleagues [69] onCD8+ T cells activated by PHA or IFN- $\gamma$.

\section{Structure and Functions of soluble HLADiversity of soluble HLA}

Immune responses to an allograft can start as a consequence of post-surgical injury and inflammation at the allograft site. One can visualize two kinds of immune reaction in the allograft. The first is similar to the hypersensitivity reaction-like Arthus vasculitisthat occurs in experimental settings following the injection of antigens. This is the interaction that may occur between donor antigens in endothelial linings (such as in vessels and glomeruli) and antibodies that may pre-exist in recipients: such antibodies do occur in the circulation of all people during their life span as pre-existing natural antibodies [84,87,97-103], either masked or free [104].The other kind of immune response occurs as a consequence of inflammatory cytokine and/or chemokine being released by allograft-infiltrating immune cells, which may include components of both innate and adaptive immunity. The cytokines may mediate upregulation of $\beta 2 \mathrm{~m}$-free HLA and HLAII, which are known to occur on activated lymphocytes, and may mediate shedding of the HLA in the allograft microenviroment and circulation, constituting a pool of soluble (s) HLA. In short, a surgical creation of a "new habitat" for an allograft generates an inflammatory platform. Both injury and inflammation-and in frequent infection-bring about the activation of immune cells, leading to the production of cytokines/chemokines that are capable of promoting overexpression of donor-derived antigens on the cell surface and/or their release into the allograft microenvironment.

\section{Early reports on the immunobiology of SHLA}

Van Rood, et al. [105] showed that sera from normal people positive for HLA-A2 could inhibit anti-HLA-A2 antibody while sera from those without HLA-A2 could not-suggesting the presence of sHLA-A2in the sera of the A2-positive. Charlton and Zmijewski [106] proved the same for the A7 sHLA of human leukocytes in the sera of people positive for HLA-A7. To validate the hypothesis proposed by these two independent groups that sHLA (A2 orA7) is responsible for blocking cytotoxicity in A2-and A7-positive patients, the sHLA should be purified from the serum and its immunogenicity documented. Terasaki and his team were the first to isolates HLA-A molecules from serum by ion exchange chromatography [107-109], using them to immunize rabbits to generate antibodies $[110,111]$. Soluble HLA was also identified in the high-density lipoprotein fractions of human plasma [112,113]. Since platelets contain $73 \%$ of the HLA molecules in the entire blood cell population, it was suggested that sHLA is derived primarily from platelets [112]. Soon after sHLA was isolated from both serum and urine, it was characterized for immunogenicity $[114,115]$. These constitute the early steps involved in isolating sHLA, all of which led to a better understanding of its role in transplantation.

\section{Two forms of sHLA classI: $\beta 2 \mathrm{~m}$-associated $\mathrm{HC}$ and B2m-free HC}

HLA molecules, like other cell-surface receptors, are internalized and subsequently re-expressed on the cell surface by "recycling" $[116,117]$. It was suggested that release of HLA molecules either after several cycles of intracellular degradation or from the cell surface contributes to the serum pool of sHLA-I $[118,119]$.Early investigators thought that shed sHLA might be in association with the membrane moieties $[106,120]$, suggesting that sHLA may occur in association with $\beta 2 \mathrm{~m}$. However, other investigators distinguished two forms of sHLA-I in human plasma and confirmed them as $\beta 2 \mathrm{~m}$-associated and $\beta 2 \mathrm{~m}$-free HLA-I [121-124]. It was postulated that if HLA molecules are shed after antigen presentation, then conformational changes may occur in the $\alpha 1$ and $\alpha 2$ helices in the absence of peptides in their groove, causing dissociation of $\beta 2 \mathrm{~m}$. Even if they are shed as $\beta 2 \mathrm{~m}$ associated sHLA, $\beta 2 \mathrm{~m}$ may become dissociated in circulation. A significant correlation between cell-surface expression of $\beta 2 \mathrm{~m}$ free HC and the amount of soluble HC of HLA was observed, the average amount of $\beta 2 \mathrm{~m}$-free $\mathrm{HC}$ in the sera determined to be 46.9 +/- $38.6 \mathrm{mM} / \mathrm{l}$ [119].

Demaria, et al. [125] further examined the nature of the two forms of HLA-I by using HLA-specific membrane-bound matrix metalloprotease (MMP) and determining whether $\beta 2 \mathrm{~m}$-free HLA could be released as HLA with "peptide-induced conformations". The group showed that dissociation of $\beta 2 \mathrm{~m}$ from the $\beta 2 \mathrm{~m}$ attached HC on the surface of lymphoblastoid (chimeric immune receptor) cells generated both conformed and non-conformed $\beta 2 \mathrm{~m}$-free $\mathrm{HC}$ as recognized by conformation-dependent antibodies. Conformed HC, having bound the HLA-A2-specific peptide (HTLV-1 tax 11-19), retained proper conformations after dissociation of $\beta 2 \mathrm{~m}$. Indeed, MMP cleaved both conformed and non-conformed surface $\beta 2 \mathrm{~m}$-free $\mathrm{HC}$ and released $\mathrm{HC}$ with preserved conformations. The Demaria team [125] also observed that exogenous $\beta 2 \mathrm{~m}$ binds only to conformed $\mathrm{HC}$, and protects them from further proteolysis. To the best of our knowledge, this is the first report explaining how both $\beta 2 \mathrm{~m}$-free and $\beta 2 \mathrm{~m}$ associated sHLA occur in circulation.

\section{Allograft-Derived soluble HLA \\ Mechanism of release of sHLA from the allograft}

The release of $\beta 2 \mathrm{~m}$-free $\mathrm{HC}$ is mediated by a $\mathrm{Zn}(2+)$ dependent MMP that does not cleave HLA-DR, CD4, or CD71 surface receptors and can be activated by phorbol myristate acetate in vitro [126]. Specific cleavage by the MMP occurs at a site close to the papain cleavage site in the $\alpha 3$ of HC. Most important, this site is not accessible to the MMP in $\beta 2 \mathrm{~m}$-associated HCthereby emphasizing the presence of $\beta 2 \mathrm{~m}$-free sHLA-I.

The mechanism underlying the genesis of sHLA-I during initiation of allograft rejection was demonstrated and discussed extensively by Burlingham and his co-investigators [127-130]. When DeVito-Haynes, et al. [127], observed donor-derived soluble $\beta 2 \mathrm{~m}$-associated HLA-I in the sera of allograft recipients who had experienced acute and chronic rejection, they 
speculated that soluble $\beta 2 \mathrm{~m}$-associated HLA-I may result from upregulation of the cell-surface expression of $\beta 2 \mathrm{~m}$-associated HLA-I during allograft rejection. Further observation led to an understanding of activation-induced upregulation of HLA-I in vitro, which serendipitously resulted in the expression of $\beta 2 \mathrm{~m}$ free HLA-I on the cell surface. Most important, these investigators also confirmed that $\beta 2 \mathrm{~m}$-free HCs, but not $\beta 2 \mathrm{~m}$-associated HCs, are cleaved by a specific MMP and released into supernatants as soluble $36 \mathrm{kDa}$ proteins. In addition, activated peripheral blood lymphocytes predominantly produced the $36 \mathrm{kDa}$ forms of sHLA proteins that appeared in the culture supernatants as both $\beta 2 \mathrm{~m}$-free $\mathrm{HC}$ and $\beta 2 \mathrm{~m}$-associated HC. Using an inhibitor of metalloproteases BB-94, the same group inhibited pokeweed mitogen-induced release of not only $\beta 2 \mathrm{~m}$-free $\mathrm{HC}$, but also $\beta 2 \mathrm{~m}$ associated HC. Investigations by both the Burlingham team [127130], Demaria team [126] showed that the possibility of $\beta 2 \mathrm{~m}$ associated HLA being cleaved directly from the cell surface is highly unlikely since $\beta 2 \mathrm{~m}$ protected the HLA HC from cleavage by the MMP. Ultimately, the presence of $\beta 2 \mathrm{~m}$-associated $\mathrm{HC}$ in culture supernatants or in serum or plasma is attributed to the re-association of shed $\beta 2 \mathrm{~m}$ with $\beta 2 \mathrm{~m}$-free HC. In support of this contention, it was shown in a rat model that soluble $\beta 2 \mathrm{~m}$-free HC can rapidly re-associate with $\beta 2 \mathrm{~m}$ [131]. These observations elucidated the role of HLA-I-specific MMP in the healthy and in generating soluble $\beta 2 \mathrm{~m}$-free and $2 \mathrm{~m}$-associated HLA during allograft rejection.

\section{Factors augmenting the release of sHLA from allografts}

Cytokines and allograft viremia: Further clarifying the mechanism underlying the formation of soluble $\beta 2 \mathrm{~m}$-free HLA, the Burlingham group showed that sHLA is actively released from primary Bronchial Epithelial Cells (BEC) by the MMP pathway [129]. The proinflammatory cytokine IFN $-\gamma$ stimulated the release of $\beta 2 \mathrm{~m}$-free HLA from the BEC in a time- and concentrationdependent manner while another proinflammatory cytokine, TNF- $\alpha$, which induces the BEC to release IL-8, had little or no effect on the release of sHLA-I. Based on reports that the inflammation caused by CMV infection augments release of sHLA in patients, the same group hypothesized that CMV infection of Endothelial Cells (EC) may induce host T cells to release IFN- $\gamma$, which in turn may activate the MMP-cleavage pathway to generate sHLA-I [130] . They analyzed sHLA-I in the supernatants of cultures of peripheral blood mononuclear cells (PBMC) containing either uninfected EC or CMV-infected EC (EC/CMV). They observed that the responder PBMC became activated and released SHLA-I by the MMP pathway when stimulated by the inflammation caused by allogeneic EC/CMV. In Transwell ${ }^{\circledR}$ cultures, IFN- $\gamma$ was released by PBMC in response to EC/CMV. In addition, the IFN- $\gamma$ recovered from the cultures stimulated release of sHLA-I from uninfected allogeneic EC; this release was also shown to be MMPdependent. These findings implied that the inflammation caused by CMV infection within the transplanted allograft will not only stimulate the release of "self" HLA from responding PBMC, but can also stimulate the release of donor sHLA-I from uninfected bystander EC, both byway of the class I MMP pathway.

Similar to CMV-mediated production of IFN- $\gamma$ and TNF- $\alpha$, stimulation of MMP and shedding of soluble HLA-I is observed after infection of EC by Japanese Encephalitis Virus (JEV), which is a single-stranded RNA virus that also leads to the production of IFN- $\gamma$ and TNF- $\alpha$, followed by the release/shedding of sHLAIb molecules [132]. An MMP inhibitor also blocked this shedding of sHLA-E. While identifying the MMP involved in the release of HLA-I as MMP-9, this team observed JEV-mediated upregulation of MMP. Addition of the UV-inactivated JEV-infected cell culture supernatants stimulated shedding of sHLA-E from uninfected EC, indicating a role for soluble factors/cytokines in the shedding process. Antibody-mediated neutralization of both TNF- $\alpha$ and IFN- $\gamma$ receptors not only resulted in the inhibition of SHLA-E shedding from uninfected cells but also inhibited HLA-E and MMP-9 gene expression in JEV-infected cells. Shedding of sHLA-E was also observed with purified TNF- $\alpha$ and IFN- $\beta$, and adding IFN- $\beta$ and TNF- $\alpha$ together further potentiated the shedding. These observations provide clear insight into the mechanism of shedding of sHLA mediated by proinflammatory cytokines with or without viral infection.

Donor Specific sHLA in allograft recipients: Observations made of liver allograft recipients elucidate the shedding of sHLA and consequent changes associated with the shed HLA. Davies, et al. [133] observed the presence of comparable levels of graftderived sHLA in the sera of liver allograft recipients and SHLA in the donor serum. Levels of sHLA in allograft recipients that increased, post-transplantation, from a detectable pre-transplant level, and the persistence of sHLA at a high level as long as the liver allograft functioned confirmed the post-transplantation shedding of sHLA by allografts. Rhynes, et al. [134] observed that the serum sHLA levels were low pre-transplant but increased substantially during the initial 10 days post-transplantation in liver $(n=9)$ and heart $(n=12)$ allograft recipients. In renal transplant patients, the increase in SHLA-I was noticed prior to or during 16 of $20(80 \%)$ biopsy-proven rejections and in 9 of 11 (83\%) after episodes of infection (bacterial, viral, and fungal).

The most compelling evidence came from the Burlingham group [135]. Using an HLA-A2-specific ELISA, they monitored both pre- and post-transplantation sera from five kidney and eight Simultaneous Pancreas-Kidney (SPK) transplants with HLA-A2-negative recipients and HLA-A2- positive donors. Donor HLA-I proteins have been found in the sera of allograft recipients at high levels (30-300 ng/ml) immediately and continuously after liver transplantation [135]. DeVito-Haynes et al. hypothesized that although donor HLA-I proteins may not be secreted continuously after kidney or pancreas-kidney transplantation, those expressed on the surface of allograft cells might be released under the stress of rejection. The group therefore, meticulously monitored pre- and post-transplantation sera daily from those five kidney and eight SPK transplants of allografts positive for HLA-A2 into HLA-A2-negative recipients. This remarkable study demonstrated that, unlike liver allografts, neither kidney nor SPK allografts continuously secrete donor HLA-I proteins. However, three of four rejection episodes in kidney recipients and all seven rejection episodes in SPK recipients resulted in the augmentation in the serum of soluble donor HLA-A2 (> $5 \mathrm{ng} / \mathrm{ml})$. 
While total sHLA levels were also elevated during rejection, the rise in DS sHLA was more dramatic when compared with pretransplantation levels. The presence of donor sHLA-I in sera is considered "a systemic indication of rejection" of allografts. The authors' concluded that detection of donor sHLA in allograft recipient sera could be a potential noninvasive biomarker of rejection, especially in the pancreas, which is currently difficult to monitor as a single-organ transplant.

McMillan, et al. [136] observed sHLA-I in the sera of 40 liver allograft donor-recipient pairs. They observed sHLA-I in sera obtained from liver donors, as well as from liver transplant recipients with End-Stage Liver Disease (ESLD) before and after transplantation at various intervals up to 3 yrs. The sHLA-I in patients with ESLD had a mean of $909+596 \mathrm{ng} / \mathrm{ml}$, greater than that in the general population $(643 \mathrm{ng} / \mathrm{ml})(p<0.05)$; sHLA-I secretion decreased as the severity of liver disease increased. In the recipients, sHLA-I levels stabilized approximately one month after transplant and remained relatively stable thereafter (mean level $950+536 \mathrm{ng} / \mathrm{ml}$ ). These observed levels were also greater than those in the general population $(p<0.05)$.

It is interestingly that an increase in serum sHLA-I levels was also observed in patients waiting for a renal allograft and undergoing Hemodialysis (HD) [137]. Sera of the HD patients (n =21) were analyzed before and after HD, and HLA-I levels were significantly higher in those undergoing HD than in the normal controls $(574.8+431.1$ vs. $415.6+256.1 \mathrm{ng} / \mathrm{ml}, p<0.05)$. Neither HD duration nor pre- and post-HD serum sHLA-I levels were different $(574.8+431.1$ vs. $568.3+398.4 \mathrm{ng} / \mathrm{ml}, p>0.05)$. After transplantation, the serum sHLA-I levels significantly decreased $(574.8+431.1$ vs. $226.7+202.8 \mathrm{ng} / \mathrm{ml}, p=0.0001)$ but increased significantly during rejection compared with the pre-rejection phase $(642.8+296.1$ vs. $305.5+194.7 \mathrm{ng} / \mathrm{ml}, p=0.0002)$. These observations suggest that SHLA-I levels are stable in uremic status and SHLA-I and could serve as a potential biomarker for monitoring acute renal allograft rejection.

Soluble HLA with serum HLA antibodies may form an immune complex: Davies, et al. [133] identified two molecular forms of SHLA-I in the sera of donors, recipients, and normal people. One of the forms of sHLA-I consists of sHLA HC monomers associated with $\beta 2 \mathrm{~m}$; the other has a molecular weight indicative of HLA antigen/antibody complexes. Rhynes, et al. [134] also noticed the presence of this SHLA-Iin one of the patients who had rejected the allograft. The molecular weight of one of the isolated sHLA forms was higher than the usual molecular weight (near 1,000,000 daltons), which was attributed to the presence of sHLA/antibody complexes in allograft recipients. It is obvious from these studies that sHLA may shed from the allograft and that the shed molecules may remain unattached or may be bound by pre-existing anti-HLA antibodies from the allograft microenvironment or by antibodies generated against sHLA for the purpose of clearing the sHLA from circulation.

Donor-specific sHLA elicits donor-specific anti-HLA antibodies: The presence of HLA antigen/anti-HLA-antibody immune complexes in patients' sera was positively associated with chronic humoral rejection $(p<0.0001)$ [138]. Following depletion of sHLA by magnetic immunoaffinity, Suciu-Foca et al. [138], could identify anti-HLA-antibodies in $57 \%$ of the sera obtained from patients undergoing chronic rejection of kidney allografts compared with the $41 \%$ identified prior to antigen depletion, thereby confirming the presence of HLA antigen/ antibody complexes in patients' sera. The primary role of the HLA antibodies may be to clear the sHLA from the circulation of the host-so anti-HLA antibodies may be generated to perform the function, some of which could be DS anti-HLA antibodies and others non-donor-specific. Zavazava, et al. [139] also noted that during acute rejection episodes-in 20 renal and 30 cardiac allograft recipients-that both serum sHLA-I/-II and the HLAantigen/antibody complexes were augmented. It was further observed that serum sHLA in 50 renal and 50 cardiac graft recipients was elevated to over 2-5 normal levels up to 10 days before histological evidence of rejection [140]. The investigators confirmed the presence of DS sHLA (A2) in one cardiac recipient. The incidence of cytotoxic anti-HLA antibodies in the sera of cardiac allograft recipients increased from $15 \%$ to $42.5 \%$ after thermal dissociation (at $56^{\circ} \mathrm{C}$ ) of sHLA from the immune complexes formed in the allograft recipients.

Mohana kumar's group, after purifying and characterizing the sHLA in liver transplant recipients that had originated both in themselves and in the donors, observed that the sHLA consisted of four major polypeptides having the molecular mass of 44, 41, 35-37, and $12 \mathrm{kD}$ complexed with IgM and IgG antibodies [141]. The sHLA-I in the lung Epithelial Lining Fluid (ELF) was also found to be enriched relative to other proteins, and it increased in lung allograft recipients who had developed chronic or acute rejection [142]. The total HLA-I from the ELF was found to contain a mixture of both donor- and recipient-type HLA-A and HLA-B proteins; and the donor-type HLA-A2 was found to be highly enriched in the ELF relative to serum.

Donor-specifics HLA immune complex in allograft rejection by vascular blockage or arteriosclerosis: Several investigators [143-148] demonstrated a strong and consistent association between serum DS HLA antibodies and arteriosclerosis. These investigators examined both the occurrence of DSA in allograft recipients' sera in the context of arteriosclerosis and the strength of the association between the DSA and the severity of arteriosclerosis. Reed, et al. [147] observed that the appearance and persistence of DS serum sHLA (A2) for more than 26 weeks following cardiac allograft put the recipients at significantly increased risk $(p<0.01)$ of developing transplant-related arteriosclerosis, which is attributed to the immunogenicity of the allograft-derived serum sHLA (A2) and production of DS HLA antibodies following transplantation Loupy, et al. [148], documented in 250 patients $(33.6 \%$ of the total cohort) with severe arteriosclerosis (luminal narrowing $>25 \%$ due to fibrointimal arterial thickening) a significant association between the circulating DS-anti-HLA antibodies and severe allograft arteriosclerosis (HR $=2.9, p<0.0001$ ). Allograft endothelial activation, endarteritis, and complement deposition were observed in patients with severe arteriosclerosis and anti- 
HLA antibodies ( $\mathrm{n}=91,12.2 \%)$. High levels of anti-HLA antibodies and their complement binding capacity were associated with increased severity of arteriosclerosis. Most important, the patients with antibody-associated severe arteriosclerosis there was decreased allograft survival and increased mortality $(p<$ 0.0001).

Direct correlation between serum donor-specifics HLA and serum creatinine levels: Glomerular tubules in the kidney are involved in the clearance of creatinine, a product of muscle metabolism. In patients with biopsy-diagnosed humoral rejection $(\mathrm{C} 4 \mathrm{~d}+)$, serum levels of both DS and NonDSHLA Antibodies (NDSA) were significantly correlated with patient serum creatinine levels [149]. Therapeutic prevention of rejection successfully reduced both DSA and NDSA and reversed humoral rejection. It is interesting that during the rejection episodes of renal allograft recipients over a 1-3 month period post-transplantation, sHLA increased significantly concomitant with a significant increase in serum creatinine levels. The return to normal serum creatinine levels are reflected in the levels of sHLA-I (0.3-1.5 micrograms/ml), a range seen in healthy persons. Notably, patients without rejection episodes maintained normal levels of sHLA [150].

Donor-specifics HLA level correlates with acute allograft rejection: Examining the sHLA levels in 252 sera of 16 liver allograft recipients, Tilg, et al. [151] observed that the sHLA-I level in six patients with acute rejection reached a peak on day $2(870+137 \mathrm{nmol} / \mathrm{L})$ from the normal level of $420+210 \mathrm{nmol} / \mathrm{L}$. However, in patients without any sign of rejection, the level of sHLA-I decreased to $277+54 \mathrm{nmol} / \mathrm{L}$ in the first 10 days posttransplant. Bacterial infection in seven allograft recipients also raised the level of sHLA, though the source of sHLA was not identified.

Similarly, Puppo, et al., [152], while monitoring sHLA-I in 16 liver allograft recipients, noted that six who had no evidence of transplant-related complications showed no change in the level of serum sHLA whereas the serum sHLA-I level were significantly raised in the 10 graft recipients with acute rejection episodes.

Rizzo, et al. [153], showed that the level of sHLA-I was significantly higher in pulmonary allograft recipients with acute rejection than in those with no rejection. Seventy-two percent of the patients with rejection had SHLA levels above the normal range, the levels peaking in the first 2 weeks posttransplantation and decreasing thereafter. Increased levels of sHLA were found in patients with acute rejection but not in those with chronic rejection or those who had infection.

Hagihara, et al. [154], examined sHLA-I changes in 33 pediatric live-donor liver recipients. Three different molecules of sHLA-I (45, 39 and 34-36 kDa) were observed. The investigators noticed a significant elevation of SHLA-I in six of eight patients who suffered episodes of acute rejection. All patients with infectious episodes also had an elevated sHLA-I level. However, increased SHLA-I was observed in 10 of 22 patients (45\%) who had no clinical complications. From 1 week to 24 months after grafting, the allograft liver released sHLA-I molecules.
Donor-specifics HLA, but not its immune complex, suppresses cytolytic activity of CD8+ $\mathrm{T}$ cells: Cell-mediated immunity is implicated in acute allograft rejection. Survival of transplanted allogeneic organs during acute rejection is strongly dependent on escaping or avoiding $\mathrm{T}$-cell reactivity against foreign MHC products. The particular species of $\mathrm{T}$ lymphocyte involved is identified as alloreactive cytotoxic CD8+ $\mathrm{T}$ cells. Parham, et al. [155], were the first to document the inhibition of alloreactive Cytotoxic T Lymphocytes (CTL) by peptides from the $\alpha 2$ domain of HLA-A2. Mathew, et al. [141], showed the HLA specificity of the CTL by demonstrating that affinitypurified sHLA-A3, but not SHLA-A2, inhibited the cytolytic activity of an HLA-A3-specific CD8+ T cell line in vitro. Smith, et al. [141], showed that sHLA-A3 inhibited CTL activity of an HLA-A3 T-cell line by 53\%whereas SHLA-A2 had no effect. Furthermore, sHLA-A3 also increased T-cell death by $77 \%$ over the control whereas sHLA-A2 had no significant effect. However, sHLA-A2 induced 21\% apoptosis of an anti-HLA-A2 T-cell line whereas sHLA-A3 caused only $3 \%$ apoptosis. A significant portion of the sHLA found in the sera of liver transplant patients is complexed with IgG and IgM antibodies. The sHLA from transplant patient sera that are complexed with DS anti-HLA antibodies are less effective in inducing apoptosis than the noncomplexed sHLA. Preincubation of $\mathrm{T}$ cells with anti-T-cell receptor mAbs protected the T cells.

The molecular mechanism underlying interaction between sHLA-I and CTL is illustrated in the works of Puppo, et al. $[156,157]$, who clearly documented that sHLA-I antigens purified from serum interact through their $\alpha 3$ domain with the $\alpha$ chain of CD8 molecules and that this interaction triggers apoptosis in PHA-activated $\mathrm{CD}^{+} \mathrm{CD}^{+} 5^{+} \mathrm{T}$ cells. These observations lend support to the contention that-after dissociation of $\beta_{2} \mathrm{~m}$-the $\beta 2 \mathrm{~m}$ free HC of HLA-I do indeed interact with CD8+ CTL through the $\alpha 3$ domain. This finding is confirmed by blocking the inhibitory effect of pre-incubating sHLA-I antigens with W6/32 mAbs that bind between the HLA class I $\alpha 3$ domain and CD8 $\alpha$ chain [158]; it is also confirmed by pre-incubation of PHA-activated CD8 ${ }^{+} \mathrm{T}$ cells with anti-CD8 $\alpha$ chain mAbs. Notably, anti- $\alpha 1$ domain HLA-I $\mathrm{mAbs}$ failed to inhibit apoptosis.

Zavazava and Kronke [159] showed that sHLA-I molecules purified from spleen lymphocytes induce apoptosis in alloreactive CD8+ T cells, upregulated CD95-L and induced apoptosis. Cell death was blocked by a neutralizing anti-CD95L antibody. All these observations clearly pinpoint the role of sHLA-I-notably, the soluble $\beta 2 \mathrm{~m}$-free HC of HLA-I-in the allograft microenvironment: it is capable of causing apoptosis of alloreactive cytotoxic CD8+ T cells, thereby preventing cellmediated rejection of allograft. It appears that the level of soluble $\beta 2 \mathrm{~m}$-free allo-HLA-I is an important factor in the prevention of acute allograft rejection. As mentioned earlier, Hagihara, et al. [154], examining SHLA-I changes in pediatric live-donor liver recipients, noted that increased levels of SHLA-I were observed in 10 of $22(45 \%)$ patients without any clinical complications. From the first week to 24 months after grafting, the allograft liver released sHLA-I molecules. Although augmentation of sHLA has 
been correlated with occurrence of acute allograft rejection, as noted earlier, the occurrence of sHLA in different molecular sizes shows that there may be several forms of SHLA-I in circulation: $\beta 2 \mathrm{~m}$-associated sHLA and $\beta 2 \mathrm{~m}$-free sHLA. Again as noted, Puppo addressed the exposure of the $\alpha 3$ domain, which is cryptic in the presence of $\beta 2 \mathrm{~m}$ and is important for CTL inhibitory function. It therefore appears that while $\beta 2 \mathrm{~m}$-free sHLAmay be associated with allograft escape from CTL attack [159], the $\beta 2 \mathrm{~m}$-associated sHLA or sHLA complexed with antibodies may work against survival of the allograft.

\section{Soluble HLA-II in Serum}

Ferrone and co-investigators were the first to detect serum sHLA-II molecules using a red blood cell rosette assay [160]. Only one of 19 normal human sera was positive for HLA-DR molecules. In contrast to healthy humans, some patients with acute and chronic lymphocytic leukemia, multiple myeloma, and Waldenstrom's macroglobulinemia had sera that contained higher levels of HLA-DR molecules. Most important, Ferrone's group further documented the immunogenicity of the soluble HLA-DR isolated from the body fluids [161].

Later, Herlyn, et al. [162] developed a detection assay with mAb DDIA to detect HLA-DR in human sera. They used two antibodies binding to different determinants of the HLA-DR molecule as a catcher and a tracer. Of 155 sera from normal people tested, only two had high levels of soluble HLA-DR. Both sera were from siblings of patients with leukemia. About $55-66 \%$ of sera from patients with Acute Lymphoblastoid Leukemia (ALL) prior to treatment had high levels of sHLA-DR in their sera. In melanoma patients, detectable levels of SHLADR in serum appeared only in the later stage of the disease. The above findings on the increased level of sHLA-DR in sera of patients with ALL were confirmed by Thompson, et al. [163], using a double-determinant ELISA with two mAbs. They further compared sHLA-II in the blood of healthy people and of patients who received either an allogeneic or autologous bone-marrow transplant. Levels were higher in pre-transplant patients than in the healthy, and in the majority of patients, these levels rose even higher at 4 weeks post-transplantation. In addition, the group also observed sHLA-II in the synovial fluid of patients with active rheumatoid arthritis. Later, Westhoff, et al. [164] utilizing two mAbs specific for HLA-DR/-DP (mAb Tii35) and HLA-DQ (mAb Tii22) measured sHLA-II molecules -DR, -DQ, -DP. The population analysis of 209 unrelated, HLA-typed healthy donors showed a mean SHLA-II protein concentration of $1.53+2.44 \mathrm{mg} /$ $\mathrm{ml}$ in plasma. McDonald, et al. [165] independently developed an ELISA to quantify sHLA-II in 702 sera obtained from normal subjects, patients with ESRD, and recipients of renal, hepatic and cardiac transplants. In transplant recipients, the McDonald group did not observe any differences in the levels of sHLA-II between pre-operative and post-transplant sera but noted that the level of sHLA-II in the sera of liver allograft recipients was significantly higher than in kidney patients, and values for heart patients were lowest of all groups.

\section{Problems associated with identifying and characterizing SHLA}

It is of interest that none of these studies addressed the question of whether sHLA-II exists as a monomer or as a dimer (as expressed on the cells).The studies contrasted their findings with those of previous observations of SHLA-I, all of which showed almost the precise reverse. It seems likely that these clear differences in SHLA-II and sHLA-I concentrations relate to different physiologic processes in either production, function, or elimination; or they involve procedural inaccuracy. Nonavailability of allele-specific mAbs could be the reason for lack of further progress in SHLA-II studies. On the other hand, the same argument applies to sHLA-I, although observations were rarely made of allele-specific sHLA-I. Most of the investigations used W6/32 as capture antibodies and $\beta 2 \mathrm{~m}$ antibodies as detection antibodies; see Table 2 in [166]. Using W6/32 is ideal for capturing soluble antigens, but it would be necessary to develop monospecific $m A b s$ for every HLA-I allele in order to characterize specifically the nature of the soluble antigens in a solid matrix assay-either ELISA or Luminex microbeads. Generating monospecific mAbs for every one of the HLA alleles would the first step. Recently, the Terasaki Foundation Laboratory has managed to identify and characterize one such HLA-I-specific monospecific $\mathrm{mAb}[84,85]$.

\section{Conclusion}

Both HLA class I and class II molecules expressed on allograft tissues are implicated in transplant rejection. Antibodies developed against the donor HLA types (DSA) are often associated with allograft rejection. However, not all patients with DSA reject donor organs. It is important to note that the poor allograft survival in patients with de novo DSA is strongly associated with acute rejection episodes; it has been observed that without acute rejection there was no difference in graft survival compared to DSA-negative cases [167]. Furthermore, in a recent study [168] of 503 patients with de novo DSA, only 120 (24\%) experienced allograft rejection. Of these, 42 developed acute rejections, 13 had de novo DSA before the acute rejection, and 12 developed DSA long after acute rejection. Comparing the 78 patients with de novo DSA who did not experience acute rejection with the 345 who did not have de novo DSA, no difference was observed in renal function. There are several other such observations in the transplant literature, suggesting that not all DSA are pathogenic. How is that possible since these antibodies, by definition, were developed specifically against the donor antigen? One possibility is that the anti-HLA antibodies may be an indicator of the presence of allograft-directed T cells. Alternatively, the anti-HLA antibodies might not be a result of the immunogencity of mismatched allo-HLA but could be due to HLA-E molecules, which are upregulated upon inflammation [169] and are capable of binding to other HLA-I molecules since they recognize epitopes shared by all HLA [87]. It is in this regard that our earlier report described how-by immunizing a non-classical HLA-Ib antigen, $\beta 2 \mathrm{~m}$-free recombinant HLA-E-we generated a group of mAbs that reacted not only to HLA-E but also to other HLA-I molecules. The anti-HLA-E mAb TFL-006 reacted with 31 HLA-A alleles, 
50 HLA-B alleles and 16 HLA-C alleles in addition to reacting well with HLA-G and HLA-F $[84,85]$. Such a polyreactive mAb is a result of the immunogenicity of the amino acid sequences in the HLA-E that are common to all other HLA. Using shared epitopes, the polyreactivity of such mAbs was blocked. All of this suggests that a soluble $\beta 2 \mathrm{~m}$-free heavy chain of HLA can elicit polyreactive antibodies against cryptic, as well as non-cryptic but shared epitopes (amino acid sequence shared by all HLA-I molecules); see Figure 2 in [170]. Such polyreactive antibodies can bind to a solid matrix (such as Luminex microbeads) coated with an HLA molecule, representing that found in allografts or in circulation. If such antibody reactivity shows high mean fluorescent intensity to one of the HLA alleles that belong to the donor HLA type, the antibodies are wrongly conceived to be DSA though they are not. Such "DSA"- even if they occur in the sera of allograft recipients-cannot be pathogenic. Moreover, such antiHLA antibodies may occur in recipients prior to transplantation (and might be mistaken for "preformed DSA") in normal people with or without infection, inflammation, or different degrees of autoimmune disease. As has been discussed elsewhere [170], only if we can identify an antibody that remains monospecific for donor-derived HLA can it be defined as pathogenic HLA. The first step in screening HLA antibodies in allograft recipients should be to identify indirectly the monospecific DS antibody that occurs only in the absence of any NDSA-specific antibodies. Such DS antibodies could be pathogenic, with the potential of rejecting an allograft.

The earliest event that occurs after transplantation appears to be the presence of SHLA, which might have been derived from the allograft. Again, this review documents the fact that sHLA is highly prevalent prior to acute rejection. So it is important to characterize the nature of the sHLA soon after transplantation, because any-or a combination-of five categories of sHLA may occur following transplantation: $\beta 2 \mathrm{~m}$-associated sHLA; $\beta 2 \mathrm{~m}$-free sHLA; membrane lipoprotein-associated $\beta 2 \mathrm{~m}$-associated sHLA; $\beta 2 \mathrm{~m}$-associated sHLA/antibody complex; and $\beta 2 \mathrm{~m}$-free sHLA/ antibody complex. It is certain that the $\alpha 3$ and $\alpha 2$ helices of HLA should be free of $\beta 2 \mathrm{~m}$ so they can interact with CD8 receptors to initiate the apoptosis of cytotoxic CD8+ T cells in the allograft microenvironment. Since the presence of alloreactive CD8+ cytotoxic $\mathrm{T}$ cells is detrimental to the survival of the allograft, eliminating CD8+ T cells is essential to save the allograft from acute rejection. Release of $\beta 2 \mathrm{~m}$-free sHLA into the allograft microenvironment by the allograft tissues is therefore the first step in escaping shock response and beginning acclimation. But this strategy for the allograft may not last long because the host immune system counteracts shed $\beta 2 \mathrm{~m}$-free sHLA as well as $\beta 2 \mathrm{~m}$ associated sHLA either by neutralizing them with pre-existing HLA antibodies or by generating novel polyreactive and/or monospecific mAbs to form an immune complex with the sHLA.

Anti-HLA antibodies, produced against the donor HLA can complex not only with sHLA but also with the cell-surface HLA of the activated endothelial cells present in the vicinity of the allograft either as arteries or as glomerular tubules. Arteriosclerosis is one of the consequences of the HLA/antibody complex in the vessels. Another complication is that such blockage can affect the glomerular filtration rate leading to increased serum creatinine levels. Whether these events occur soon after transplant or long after transplant, they are bound to cause rejection of the allograft. There are not yet any studies that show whether antibodies are produced against the glycosylation residues of HLA. Often, IgM antibodies are elicited against glycosyl residues and production of such antibodies occurs in a T-cell-independent manner involving CD5+ B1 B cells. Such IgM antibodies can be expected to exert a highly deleterious effect on the allograft if they pass through the endothelial venules.

While the HLA molecule is the centerpiece of the immunobiology of transplantation, the soluble HLA molecule is an important player in allograft survival or rejection. Two considerations make it seem unlikely that the involvement of sHLA in allograft outcome is merely a bystander effect. First, there is the ability of the sHLA to bind to receptors on CD8+ T cells [171,156-159], with such interaction capable of inducing apoptosis of CD8+ cells and arresting of cytolytic capability $[141,156,157]$. Second, there is the recent report of a monospecific monoclonal anti-HLA-E antibody able to induce proliferation and blastogenesis of CD8+ cells in vitro [93]. Both phenomena point to a therapeutic strategy. It is also important to note that it is not just one kind of soluble mismatched HLA that occurs in the blood of allograft recipients; there are, at minimum, two different kinds$\beta 2 \mathrm{~m}$-free and $\beta 2 \mathrm{~m}$-associated heavy chains of soluble allo-HLA. The functional distinctions of these two kinds of sHLA require further study. Furthermore, the role of glycosylation residues of HLA deserves more serious attention in the future to obtain a full picture of organ rejection post-transplantation.

\section{Acknowledgement}

This project is supported from the grants from Terasaki Family Foundation and facilities from Terasaki Foundation Laboratory. We profusely thank our research associates at Terasaki Foundation Laboratory: Judy Hopfield, Anh Nguyen, Nubia Banuelos and Curtis Maehara for critically reading the manuscript and offering suggestions for its improvement.

\section{Conflicts of Interest}

None of the authors have any conflict of interest or financial support other than that mentioned in the acknowledgements.

\section{References}

1. van Rood JJ, van Leeuwen A. Leukocyte grouping. A method and its application. J Clin Invest. 1963;42:1382-1390.

2. Bosch LJ, Eernisse JG, van Leeuwen A, Loeliger EA, van Rood JJ. Treatment of thromobocytopenic patients with repeated platelet transfusions. Rev Belg Pathol Med Exp. 1965;31:139-145.

3. Terasaki PI, Marchioro TH, Starzl TE. Sero-typing of human lymphocyte antigens. In Conference on Histocompatibility Testing. Washington, DC; 1964.

4. Terasaki PI, Cannon JA, Longmire WP Jr. Antibody response to homografts. I. Technic of lymphoagglutination and detection of lymphoagglutining upon spleen injection. Proc Soc Exp Biol Med. 1959;102:280-285. 
5. Terasaki PI, Antibody response to homogratfs. II. Preliminary studies of the time of appearance of lymphoagglutinins upon homografting. Am Surg. 1959;25:896-899.

6. Terasaki PI, Cannon JA, Longmire WP Jr. Time-lapse cinematography studies of the in vitro action of serum from homografted animals. Surg Forum. 1960;10:865-868.

7. Terasaki PI, Cannon JA, Longmire WP Jr. Antibody response to homografts. IV. Time of appearance of lymphoagglutinins in partially tolerant animals. Transplant Bull. 1960;7:415-418.

8. Terasaki PI, Cannon JA, Longmire WP Jr. Antibody response to homografts. VI. In vitro cytotoxins produced by skin homografts in rabbits. Proc Soc Exp Biol Med. 1961;106:133-136.

9. Terasaki PI, McClelland JD, Cannon JA, Longmire WP Jr. Antibody response to homografts. VII. The role of complement in cytotoxicity of serum from homografted rabbits. J Immunol. 1961;87:39-45.

10. Terasaki PI, Cannon JA, Longmire WP Jr, Chamberlain, CC. Antibody response to homografts: V. Cytotoxic effects upon lymphocytes as measured by time-lapse cinematography. Ann N Y Acad Sci. 1960;87:258-265.

11. Colombani J, Colombani M, Dausset J. Leukocyte antigens and skin homograft in man. Demonstration of humoral antibodies after homografting by the antiglobulin consumption test. Ann N Y Acad Sci. 1964;120:307-21.

12. Dausset J, Brecy H, Lal VB, Identity of leukocytic antigens detectable from immune iso-leuko-agglutinins in monozygotic twins. C R Seances Soc Biol Fil. 1957;151(2):244-246.

13. Patel R, Mickey MR, Terasaki PI. Serotyping for homotransplantation. XVI. Analysis of kidney transplants from unrelated donors. N Engl J Med. 1968;279(10):501-506.

14. Patel R, Terasaki PI. Significance of the positive crossmatch test in kidney transplantation. N Engl J Med. 1969; 280(14):735-739.

15. Wang GX, Terashita GY, Terasaki PI. Platelet crossmatching for kidney transplants by flow cytometry. Transplantation. 1989;48(6):959-961.

16. Mickey MR, Ayoub G, Terasaki PI. Prediction of negative crossmatch: an aid for cost-effective kidney sharing. Transplant Proc. 1982;14(2):279-281.

17. Ting A, Terasaki PI. Lymphocyte-dependent antibody cross-matching for transplant patients. Lancet. 1975; 1(7902):304-306.

18. Pei R, Lee J, Chen T, Rojo S, Terasaki PI. Flow cytometric detection of HLA antibodies using a spectrum of microbeads. Hum Immunol. 1999;60(12):1293-1302.

19. Pei R, Lee JH, Shih NJ, Chen M, Terasaki PI. Single human leukocyte antigen flow cytometry beads for accurate identification of human leukocyte antigen antibody specificities. Transplantation. 2003;75(1):43-49.

20. Qiu J, Cai J, Terasaki PI, El-Awar N, Lee JH. Detection of antibodies to HLA-DP in renal transplant recipients using single antigen beads. Transplantation. 2005;80(10):1511-1513.

21. El-Awar N, Lee J, Terasaki PI. HLA antibody identification with single antigen beads compared to conventional methods. Hum Immunol. 2005;66(9):989-997.

22. Terasaki PI. Humoral theory of transplantation. Am J Transplant. 2003;3(6):665-673.

23. Terasaki PI. A personal perspective: 100-year history of the humoral theory of transplantation. Transplantation.

\section{2;93(8):51-6. doi: 10.1097/TP.0b013e3182483713.}

24. Robinson J, Halliwell JA, Hayhurst JD, Flicek P, Parham P, Marsh SG. The IPD and IMGT/HLA database: allele variant databases. Nucleic Acids Res. 2015;43:D423-D431. doi: 10.1093/nar/gku1161.

25. Ryan SO, Cobb BA. Roles for major histocompatibility complex glycosylation in immune function. Semin Immunopathol. 2012;34(3):425-441.doi: 10.1007/s00281-012-0309-9.

26. Parham P, Alpert BN, Orr HT, Strominger JL. Carbohydrate moiety of HLA antigens. Antigenic properties and amino acid sequences around the site of glycosylation. J Biol Chem. 1977;252(21):7555-7567.

27. Rudd PM, Wormald MR, Stanfield RL, Huang M, Mattsson N, Speir JA, et al. Roles for glycosylation of cell surface receptors involved in cellular immune recognition. J Mol Biol. 1999;293(2):351-366.

28. Rudd PM, Elliott T, Cresswell P, Wilson IA, Dwek RA. Glycosylation and the immune system. Science. 2001 ;291(5512):2370-2376.

29. Gauthier L, Smith KJ, Pyrdol J, Kalandadze A, Strominger JL, Wiley DC, et al. Expression and crystallization of the complex of HLA-DR2 (DRA, DRB1*1501) and an immunodominant peptide of human myelin basic protein. Proc Natl Acad Sci USA. 1998;95(20):11828-11833.

30. Ryan SO, Bonomo JA, Zhao F, Cobb BA. MHCII glycosylation modulates Bacteroides fragilis carbohydrate antigen presentation. J Exp Med. 2011;208(5):1041-1053. doi: 10.1084/jem.20100508.

31. Bergeron JJ, Zapun A, Ou WJ, Hemming R, Parlati F, Cameron PH, et al. The role of the lectin calnexin in conformation independent binding to N-linked glycoproteins and quality control. Adv Exp Med Biol. 1998;435:105-116.

32. Trombetta ES, Helenius A. Lectins as chaperones in glycoprotein folding. Curr Opin Struct Biol. 1998;8(5):587-592.

33. Saito Y, Ihara Y, Leach MR, Cohen-Doyle MF, Williams DB. Calreticulin functions in vitro as a molecular chaperone for both glycosylated and non-glycosylated proteins. EMBO J. 1999;18(23):6718-6729.

34. Néel D, Merlu B, Turpin E, Rabourdin-Combe C, Mach B, Goussault $\mathrm{Y}$, et al. Characterization of N-linked oligosaccharides of an HLA-DR molecule expressed in different cell lines. Biochem J. 1987;244(2):433442

35. Merlu B, Neel D, Goussault Y, Charron DJ. Glycosylation of human leukocyte locus A molecules is dependent on the cell type. Eur J Biochem. 1989;181(3):755-760.

36. Wilkinson GWG, Aicheler RJ, Wang ECY. In: Reddehasse M (ed). Cytomegaloviruses: From molecular pathogenesis to intervention. Wymondham, Norfolk: Caister Academic Press; 2013. p.172-190.

37. Alexander S, Hubbard SC, Strominger JL. HLA-DR antigens of autologous melanoma and B lymphoblastoid cell lines: differences in glycosylation but not protein structure.J Immunol. 1984;133(1):315320.

38. Campbell BJ, Yu LG, Rhodes JM. Altered glycosylation in inflammatory bowel disease: a possible role in cancer development. Glycoconj J 2001;18:851-858.

39. Bodger K, Halfvarson J, Dodson AR, Campbell F, Wilson S, Lee R, et al. Altered colonic glycoprotein expression in unaffected monozygotic twins of inflammatory bowel disease patients. Gut. 2006;55:973-977.

40. Barrera, C, Espejo R, Reyes VE. Differential glycosylation of MHC class II molecules on gastric epithelial cells: implications in local immune responses. Hum Immunol 2002;63(5):384-393.

41.Wormald MR, Dwek RA. Glycoproteins: glycan presentation and 
protein-fold stability. Structure. 1999;7(7): R155-60.

42. Dustin ML, Golan DE, Zhu DM, Miller JM, Meier W, Davies EA, et al. Low affinity interaction of human or rat $\mathrm{T}$ cell adhesion molecule CD2 with its ligand aligns adhering membranes to achieve high physiological affinity. J Biol Chem. 1997;272(49):30889-30898.

43. Ploegh HL, Orr HT, Stominger JL. Biosynthesis and cell surface localization of nonglycosylated human histocompatibility antigens. J Immunol. 1981;126(1):270-5.

44. Barnstable CJ, Bodmer WF, Brown G, Galfre G, Milstein C, Williams $\mathrm{AF}$, et al. Production of monoclonal antibodies to group A erythrocytes, HLA and other human cell surface antigens-new tools for genetic analysis. Cell. 1978;14(1): 9-20.

45. Parham P, Barnstable CJ, Bodmer WF. Use of a monoclonal antibody (W6/32) in structural studies of HLA-A, B, C, antigens. J Immunol. 1979;123(1):342-9.

46. Quaranta V, Walker LE, Ruberto G, Pellegrino MA, Ferrone S. The free and the beta 2 microglobulin-associated heavy chains of HLA-A, $\mathrm{B}$ alloantigens share the antigenic determinant recognized by the monoclonal antibody Q1/28. Immunogenetics. 1981;13(4):285-95.

47. Benjamin RJ, Abrams JR, Parnes JR, Madrigal JA, Parham P. Polymorphic specificity of Q1/28, a monoclonal antibody that preferentially reacts with free class I heavy chains. Immunogenetics. 1992;37(1):73-76.

48. Stam NJ, Spits H, Ploegh HL. Monoclonal antibodies raised against denatured HLA-B locus heavy chains permit biochemical characterization of certain HLA-C locus products. J Immunol. 1986;137(7):2299-2306.

49. Brodsky FM, Parham P, Barnstable CJ, Crumpton MJ, Bodmer WF. Monoclonal antibodies for analysis of the HLA system. Immunol Rev. 1979;47:3-61.

50.Wilson BS, Glassy MC, Quaranta V, Ng AK, Ferrone S. Effect of tunicamycin on the assembly and antigenicity of HLA antigens: analysis with monoclonal antibodies. Scand J Immunol. 1981;14(2):201-205.

51. Filippone EJ, Farber JL. Humoral Immune Response and Allograft Function in Kidney Transplantation. Am J Kidney Dis. 2015;66(2):337347. doi: 10.1053/j.ajkd.2015. 03. 033l.

52. Krangel MS, Orr HT, Strominger JL. Assembly and maturation of HLA-A and HLA-B antigens in vivo. Cell. 1979; 18(4):979-991.

53. Rock KL, Gamble S, Rothstein L, Gramm C, Benacerraf B. Dissociation of beta 2 microglobulin leads to the accumulation of a substantial pool of inactive class I MHC heavy chains on the cell surface. Cell. 1991;65(4):611-620.

54. Raine T, Brown D, Bowness P, Hill Gaston JS, Moffett A, Trowsdale J, et al. Consistent patterns of expression of HLA class I free heavy chains in healthy individuals and raised expression in spondyloarthropathy patients point to physiological and pathological roles. Rheumatology (Oxford). 2006;45(11):1338-1344.

55. Rigney E, Kojima M, Glithero A, Elliott T. A soluble major histocompatibility complex class I peptide-binding platform undergoes a conformational change in response to peptide epitopes. J Biol Chem. 1998;273(23):14200-14204.

56. Springer S, Döring K, Skipper JC, Townsend AR, Cerundolo V. Fast association rates suggest a conformational change in the MHC class I molecule H-2Db upon peptide binding. Biochemistry, 1998;37:30013012.

57. Yaneva R, Schneeweiss C, Zacharias M, Springer S. Peptide binding to MHC class I and II proteins: new avenues from new methods. Mol Immunol. 2010;47(4):649-657.

58. Schnabl E, Stockinger H, Majdic O, Gaugitsch H, Lindley IJ, Maurer $\mathrm{D}$, et al. Activated human T lymphocytes express MHC class I heavy chains not associated with beta 2microglobulin. J Exp Med. 1990;171(5):1431-1442.

59. Schumacher TN, Heemels MT, Neefjes JJ, Kast WM, Melief CJ, and Ploegh HL. Direct binding of peptide to empty MHC class I molecules on intact cells and in vitro. Cell. 1990;62:563 -567.

60. Benjamin RJ, Madrigal JA, and Parham P. Peptide binding to empty HLA-B27 molecules of viable human cells. Nature. 1991;351(6321):7477.

61. Majdic O, Schnabl E, Stockinger H, Gadd S, Maurer D, Radaszkiewics $\mathrm{T}$, et al. LA45, an activation-induced human lymphocyte antigen with strong homology to MHC class I molecules. In Leukocyte Typing IV. Oxford University Press, 1989; p. 511.

62. Madrigal JA, Belich MP, Benjamin RJ et al. Molecular definition of a polymorphic antigen (LA45) of free HLA-A and -B heavy chains found on the surfaces of activated B and T cells. J Exp Med. 1991;174(5):1085-1095.

63. Santos SG, Powis SJ, Arosa FA. Misfolding of major histocompatibility complex class I molecules in activated T cells allows cis-interactions with receptors and signaling molecules and is associated with tyrosine phosphorylation. J Biol Chem. 2004;279(51):53062-53070.

64. Arosa FA, Santos SG, Powis SJ. Open conformers: the hidden face of MHC-I molecules. Trends Immunol 2007; 28(3):115-23.

65. Allen RL, O’Callaghan CA, McMichael AJ, Bowness P. Cutting edge: HLA-B27 can form a novel 2 microglobulin-free $\mathrm{H}$ chain homodimer structure. J. Immunol. 1999;162:5045-5048.

66. Khare SD, Hansen J, Luthra HS, David CS. HLA-B27 heavy chains contribute to spontaneous inflammatory disease in B27/human beta2microglobulin (beta2 $\mathrm{m}$ ) double transgenic mice with disrupted mouse beta2m. J Clin Invest. 1996; 98(12):2746-2755.

67. Capps GG, Robinson BE, Lewis KD, Zúñiga MC. In vivo dimeric association of class I MHC heavy chains. Possible relationship to class I MHC heavy chain-beta 2 microglobulin dissociation. J Immunol. 1993;151(1):159-169.

68. Chakrabarti A, Matko J, Rahman NA, Barisas BG, Edidin M. Self-association of class I major histocompatibility complex molecules in liposome and cell surface membranes. Biochemistry. 1992;31(31):7182-9.

69. Matko J, Bushkin Y, Wei T, Edidin M. Clustering of class I HLA molecules on the surfaces of activated and transformed human cells. J Immunol. 1994;152(7):3353-3360.

70. Triantafilou K, Triantafilou M, Wilson KM, Fernandez N. Human major histocompatibility molecules have the intrinsic ability to form homotypic associations. Hum Immunol. 2000;61(6):585-98.

71. Allen RL, Raine T, Haude A, Trowsdale J, Wilson MJ. Leukocyte receptor complex-encoded immunomodulatory receptors show differing specificity for alternative HLA-B27 structures. J Immunol. 2001;167(10):5543-5547.

72. Rodriguez MA, De Sanctis JB, Blasini AM, Leon-Ponte M, Abadi I. Human IFN-gamma up-regulates IL-2 receptors in mitogenactivated T lymphocytes. Immunology. 1990;69:554-557.

73. Modai D, Berman S, Sheleg Y, Cohn M, Weissgarten J, Averbukh Z. 
Interleukin-2 receptor is similarly expressed by activated lymphocytes from patients on chronic hemodialysis and healthy subjects. Clin Immunol Immunopathol. 1990;55(2):237-241.

74. Stentz FB, Kitabchi AE. Transcriptome and proteome expression in activated human CD4 and CD8 T-lymphocytes. Biochem Biophys Res Commun. 2004;324(2):692-696.

75. Engelhardt W, Matzke J, Schmidt RE. Activation-dependent expression of low affinity IgG receptors Fc gamma RII(CD32) and Fc gamma RIII(CD16) in subpopulations of human T lymphocytes. Immunobiology . 1995;192(5):297-320.

76. Kawabe T,Maekawa N,Maeda Y, Hosoda M, Yodoi J. Induction of Fc epsilon RII/CD23 on phytohemagglutinin-activated human peripheral blood T lymphocytes. I. Enhancement by IL-2 and IL-4. J Immunol. 1991;147:548-553.

77. Stentz FB, Kitabchi AE. Hyperglycemia-induced activation of human T-lymphocytes with de novo emergence of insulin receptors and generation of reactive oxygen species. Biochem Biophys Res Commun. 2005;335(2):491-495.

78. Torres JM, Laborda J, Naval J, Darracq N, Calvo M, Mishal Z, et al Expression of alpha-fetoprotein receptors by human T-lymphocytes during blastic transformation. Mol Immunol. 1989;26(9):851-857.

79. Carrel S, Salvi S, Isler P, Rapin C, Hayoz D, Gallay P, et al. gp33-38, an early human T cell activation antigen. J Immunol. 1990;144:20532062.

80. Molinero LL, Fuertes MB, Rabinovich GA, Fainboim L, Zwirner NW. Activation-induced expression of MICA on T lymphocytes involves engagement of CD3 and CD28. J Leukoc Biol. 2002;71:791-797.

81. Tate G, Katagiri M. Analysis of HLA-class II antigen mRNAs on T lymphoblasts. Hokkaido Igaku Zasshi. 1986; 61(2):249-256.

82. Moriya N, Sanjoh K, Yokoyama S, Hayashi T. Mechanisms of HLA-DR antigen expression in phytohemagglutinin-activated $\mathrm{T}$ cells in man. Requirement of T cell recognition of self HLA-DR antigen expressed on the surface of monocytes. J Immunol. 1987;139:3281-3286.

83. Puppo F, Gurreri G, Pattarini R, Ranise A, Indiveri F. Proliferation in autologous mixed lymphocyte reactions, expression of HLA class II antigen and serum immunomodulatory activity in patients with renal insufficiency on chronic dialysis. Allergol Immunopathol (Madr). 1991;19(4):167-173.

84. Ravindranath MH, Terasaki PI, Pham T, Jucaud V, Kawakita S. Therapeutic preparations of IVIg contain naturally occurring antiHLA-E antibodies that react with HLA-Ia (HLA-A/-B/-Cw) alleles. Blood. 2013;121(11):2013-2028. doi: 10.1182/blood-2012-08-447771.

85. Ravindranath MH, Zhu D, Pham T, Jucaud V, Hopfield J, Kawakita S, et al. Anti-HLA-E monoclonal antibodies reacting with HLA-la and lb alleles like IVIg as potential IVIg-immunomimetics: an evolving therapeutic concept. Clin Transpl. 2013;293-305.

86. Ravindranath MH, Taniguchi M, Chen CW, Ozawa M, Kaneku H, ElAwar N, Cai J, Terasaki PI. HLA-E monoclonal antibodies recognize shared peptide sequences on classical HLA class Ia: relevance to human natural HLA antibodies. Mol Immunol. 2010;47(5):1121-1131. doi: 10.1016/j.molimm.2009.

87. Ravindranath MH, Kaneku H, El-Awar N, Morales-Buenrostro LE, Terasaki PI. Antibodies to HLA-E in nonalloimmunized males: pattern of HLA-Ia reactivity of anti-HLA-E-positive sera. J Immunol. 2010;185(3):1935-1948. doi: 10.4049/ jimmunol.1000424.

88. Ravindranath MH, Pham T, El-Awar N, Kaneku H, Terasaki PI. Anti-
HLA-E mAb 3D12 mimics MEM-E/02 in binding to HLA-B and HLA-C alleles: Web-tools validate the immunogenic epitopes of HLA-E recognized by the antibodies. Mol Immunol. 2011;48(4):423-430. doi: 10.1016/j.molimm.2010.09.011.

89. Allen RL, Trowsdale J. Recognition of classical and heavy chain forms of HLA-B27 by leukocyte receptors. Curr Mol Med. 2004;4(1):59-65.

90.Santos SG, Antoniou AN, Sampaio P, Powis SJ, Arosa FA. Lack of tyrosine 320 impairs spontaneous endocytosis and enhances release of HLA-B27 molecules. J Immunol. 2006;176:2942-2949.

91. Ravindranath MH, Terasaki PI, Pham T, Jucaud V. The Monospecificity of Novel Anti-HLA-E Monoclonal Antibodies Enables Reliable Immunodiagnosis, Immunomodulation of HLA-E, and Upregulation of CD8+ T Lymphocytes. Monoclon Antib Immunodiagn Immunother. 2015;34(3):135-53. doi: 10.1089/mab.2014.0096.

92. Sasaki T, Ravindranath MH, Terasaki PI, Freitas MC, Kawakita S, Jucaud V. Gastric cancer progression may involve a shift in HLA-E profile from an intact heterodimer to $\beta 2$ microglobulin-free monomer. Int J Cancer. 2014;134(7):1558-1570. doi: 10.1002/ijc.28484.

93. Ravindranath MH, Pham T, Ozawa M, Terasaki PI. Antibodies to HLA-E may account for the non-donor-specific anti-HLA class-Ia antibodies in renal and liver transplant recipients. Int Immunol. 2012;24(1):4357.

94.Zhu D, Ravindranath MH, Terasaki PI, Miyazaki T, Pham T, Jucaud V. Suppression of allo-human leucocyte antigen (HLA) antibodies secreted by B memory cells in vitro: intravenous immunoglobulin (IVIg) versus a monoclonal anti-HLA-E IgG that mimics HLA-I reactivities of IVIg. Clin Exp Immunol. 2014;177(2):464-477. doi: 10.1111/cei.12307

95. Ravindranath MH, Terasaki PI, Pham T, Jucaud V, Kawakita S. Suppression of blastogenesis and proliferation of activated CD4(+) $\mathrm{T}$ cells: intravenous immunoglobulin (IVIg) versus novel anti-human leucocyte antigen (HLA)-E monoclonal antibodies mimicking HLA-I reactivity of IVIg. Clin Exp Immunol. 2014;178(1):154-177. doi: 10.1111/cei.12391.

96. Guild BC, Strominger JL. Human and murine class I MHC antigens share conserved serine 335, the site of HLA phosphorylation in vivo. J Biol Chem. 1984;259:9235-9240.

97. Billing R, Terasaki PI. Human leukemia antigen. I. Production and characterization of antisera. J Natl Cancer Inst. 1974;53(6):16351638.

98. Aster RH, Miskovich BH, Rodey GE. Histocompatibility antigens of human plasma. Localization to the HLD-3 lipoprotein fraction. Transplantation. 1973;16(3):205-210.

99. Rittner C, Täuberecht I. Demonstration of HL-A inhibitors in human serum. I. Does an association exist between HL-A and serum lipoproteins? ZImmunitatsforsch Exp Klin Immunol. 1973;146(2):123135.

100. Oh SK, Pellegrino MA, Ferrone S, Sevier ED, Reisfeld RA. Soluble HL-A antigens in serum. I. Isolation and purification. Eur J Immunol. 1975;5(3):161-166.

101. Reisfeld RA, Allison JP, Ferrone S, Pellegrino MA, Poulik MD. HL-A antigens in serum and urine: isolation, characterization, and immunogenic properties. Transplant Proc. 1976;8(2):173-178.

102. Machy P, Truneh A, Gennaro D, Hoffstein S. Major histocompatibility complex class I molecules internalized via coated pits in $\mathrm{T}$ lymphocytes. Nature. 1987;328(6132):724-726. 
103. Machy P, Truneh A, Gennaro D, Hoffstein S. Endocytosis and de novo expression of major histocompatibility complex encoded class I molecules: kinetic and ultrastructural studies. Eur J Cell Biol. 1987;45(1):126-136.

104. Reid PA, Watts C. Cycling of cell-surface MHC glycoproteins through primaquine-sensitive intracellular compartments. Nature. 1990;346(6285):655-657.

105. Pickl WF, Majdic O, Faé I, Reuschel R, Holter W, Knapp W. The soluble pool of beta 2 microglobulin free HLA class I alpha-chains. Qualitative and quantitative characterization. J Immunol. 1993;151(5):26132622.

106. Allison JP, Pellegrino MA, Ferrone S, Callahan GN, Reisfeld RA. Biologic and chemical characterization of HLA antigens in human serum. J.Immunol. 1977;118(3):1004-1009.

107. Krangel MS. Two forms of HLA class I molecules in human plasma. Hum Immunol. 1987;20(2):155-165.

108. Pollard SG, Davies HF, Calne RY: Preoperative appearance of serum class I antigen during liver transplantation. Transplantation. 1990;49(3):659-660.

109. Demaria S, Schwab R, Bushkin Y.The origin and fate of beta $2 \mathrm{~m}$-free MHC class I molecules induced on activated T cells. Cell Immunol. 1992;142(1):103-113.

110. Demaria S, Bushkin Y. CD8 and beta 2microglobulin-free MHC class I molecules in T cell immunoregulation. Int J Clin Lab Res. 1993;23(2):61-69.

111. Demaria S, DeVito-Haynes LD, Salter RD, Burlingham WJ, Bushkin Y. Peptide-conformed beta $2 \mathrm{~m}$-free class I heavy chains are intermediates in generation of soluble HLA by the membrane-bound metalloproteinase. Hum Immunol. 1999;60(12):1216-1226.

112. Demaria S, Schwab R, Gottesman SR, Bushkin Y. Soluble beta 2 microglobulin-free class I heavy chains are released from the surface of activated and leukemia cells by a metalloprotease. J Biol Chem. 1994;269(9):6689-6694.

113. DeVito-Haynes LD, Demaria S, Bushkin Y, Burlingham WJ. The metalloproteinase-mediated pathway is essential for generation of soluble HLA class I proteins by activated cells in vitro: proposed mechanism for soluble HLA release in transplant rejection.Hum Immunol. 1998;59(7):426-434.

114. DeVito-Haynes LD, Jankowska-Gan E, Meyer KC, Cornwell RD, Zeevi A, Griffith B, et al. Soluble donor HLA class I and beta $2 \mathrm{~m}$-free heavy chain in serum of lung transplant recipients: steady-state levels and increases in patients with recurrent CMV infection, acute rejection episodes, and poor outcome. Hum Immunol. 2000;61(12):13701382.

115. Haynes LD, Bushkin Y, Love RB, Burlingham WJ. Interferon-gamma drives the metalloproteinase-dependent cleavage of HLA class I soluble forms from primary human bronchial epithelial cells. Hum Immunol. 2002;63(10):893-901.

116. Haynes LD, Waldman WJ, Bushkin Y, Love RB, Burlingham WJ. CMV-infected allogeneic endothelial cells initiate responder and bystander donor HLA class I release via the metalloproteinase cleavage pathway. Hum Immunol. 2005; 66(3):211-221.

117. Zhai Y, Knechtle S. Two distinct forms of soluble MHC class molecules synthesized by different mechanisms in normal rat cells in vitro. Hum Immunol. 1998;59(7):404-414.

118. Shwetank, Date OS, Kim KS, Manjunath R. Infection of human endothelial cells by Japanese encephalitis virus: increased expression and release of soluble HLA-E. PLoS One. 2013;8(11):e79197. doi: 10.1371/journal.pone.0079197.

119. Davies HS, Pollard SG, Calne RY. Soluble HLA antigens in the circulation of liver graft recipients.Transplantation. 1989;47(3):524527.

120. Rhynes VK, McDonald JC, Gelder FB, Aultman DF, Hayes JM, McMillan RW, et al. Soluble HLA class I in the serum of transplant recipients. Ann Surg. 1993;217(5):485-489.

121. DeVito-Haynes LD, Jankowska-Gan E, Sollinger HW, Knechtle SJ, Burlingham WJ. Monitoring of kidney and simultaneous pancreaskidney transplantation rejection by release of donor-specific, soluble HLA class I. Hum Immunol. 1994;40(3):191-201.

122. McMillan RW, Gelder FB, Zibari GB, Aultman DF, Adamashvili I, McDonald JC. Soluble fraction of class I human histocompatibility leukocyte antigens in the serum of liver transplant recipients. Clin Transplant. 1997;11(2):98-103.

123. Yang CW, Kim TG, Kim YS, Han H, Chang YS, Yoon YS, et al. Serum soluble HLA class I antigen levels in Hemodialysis patients and following renal transplantation. Am J Nephrol. 1995;15(4):290-294.

124. Suciu-Foca N, Reed E, D'Agati VD, Ho E, Cohen DJ, Benvenisty AI, et al. Soluble HLA antigens, anti-HLA antibodies, and antiidiotypic antibodies in the circulation of renal transplant recipients. Transplantation. 1991;51(3):593-601.

125. Zavazava N, Hausmann R, Kraatz E, Müller-Ruchholtz W. Clinical relevance of soluble HLA and interaction of papain derived class I molecules with alloreactive CTL. Transpl Int. 1992;1:S606-8.

126. Zavazava N, Bottcher H, Ruchholtz WM. Soluble MHC class I antigens sHLA and anti-HLA antibodies in heart and kidney allograft recipients. Tissue Antigens. 1993;42:20-26.

127. Mathew JM, Shenoy S, Phelan D, Lowell J, Howard T, Mohanakumar T. Biochemical and immunological evaluation of donor-specific soluble HLA in the circulation of liver transplant recipients. Transplantation. 1996;62(2):217-223.

128. DeVito-Haynes LD, Jankowska-Gan E, Heisey DM, Cornwell RD, Meyer KC, Love RB, et al. Soluble HLA class I in epithelial lining fluid of lung transplants: associations with graft outcome. Hum Immunol. 1997;52(2):95-108.

129. Colvin RB. Antibody-mediated renal allograft rejection: Diagnosis and pathogenesis. J Am Soc Nephrol. 2007;18(4):1046-1056.

130. Cornell LD, Smith RN, Colvin RB. Kidney transplantation: Mechanisms of rejection and acceptance. Annu Rev Pathol. 2008;3:189-220.

131. Shimizu T, Ishida H, Shirakawa H, Omoto K, Tsunoyama K, Tokumoto $\mathrm{T}$, et al. Clinicopathological analysis of acute vascular rejection cases after renal transplantation. Clin Transplant. 2010;22:22-26. doi: 10.1111/j.1399-0012.2010.01277.x.

132. Lefaucheur C, Loupy A, Vernerey D, Duong-Van-Huyen JP, Suberbielle C, Anglicheau D, et al. Antibody-mediated vascular rejection of kidney allografts: a population-based study. Lancet. 2013;381(9863):313319. doi: 10.1016/S0140-6736(12)61265-3.

133. Reed EF, Hong B, Ho E, Harris PE, Weinberger J, Suciu-Foca N. Monitoring of soluble HLA alloantigens and anti-HLA antibodies identifies heart allograft recipients at risk of transplant-associated coronary artery disease. Transplantation. 1996;61(4):566-572.

134. Loupy A, Vernerey D, Viglietti D, Aubert O, Van Huyen JP, Empana JP, et al. Determinants and Outcomes of Accelerated Arteriosclerosis: 
Major Impact of Circulating Antibodies. Circ Res. 2015;117(5):47082. Doi: 10.1161/CIRCRESAHA.117.306340.

135. Cai J, Terasaki PI, Bloom DD, Torrealba JR, Friedl A, Sollinger HW, et al Correlation between human leukocyte antigen antibody production and serum creatinine in patients receiving sirolimus monotherapy after Campath-1H induction. Transplantation. 2004;78(6): 919-924.

136. Zavazava N, Leimenstoll G, Müller-Ruchholtz W. Measurement of soluble MHC class I molecules in renal graft patients: a noninvasive allograft monitor. J Clin Lab Anal. 1990;4(6):426-429.

137. Tilg H, Westhoff U, Vogel W, Aulitzky WE, Herold M, Margreiter $\mathrm{R}$, et al. Soluble HLA class I serum concentrations increase with transplant-related complications after liver transplantation. J Hepatol. 1992;14(2-3):417-419.

138. Puppo F, Pellicci R, Brenci S, Nocera A, Morelli N, Dardano G, et al. HLA class-I-soluble antigen serum levels in liver transplantation. A predictor marker of acute rejection. Hum Immunol. 1994;40(3):166170.

139. Rizzo M, Sundaresan S, Lynch J, Trulock EP, Cooper J, Patterson GA, et al. Increased concentration of soluble human leukocyte antigen class I levels in the bronchoalveolar lavage of human pulmonary allografts. J Heart Lung Transplant. 1997;16(11):1135-1140.

140. Hagihara M, Munkhbat B, Kanai N, Shimura T, Kiuchi T, Inomata $\mathrm{Y}$, et al. Serum soluble human leucocyte antigen class $\mathrm{I}$ in paediatric liver transplantation with live, related donors. Transpl Immunol. 1997;5(3):219-224.

141. Parham P. Clayberger C, Zorn SL, Ludwig DS, Schoolnik GK, Krensky AM. Inhibition of alloreactive cytotoxic T lymphocytes by peptides from the $\alpha$-2 domain of HLA-A2. Nature. 1987;325:625-628.

142. Smith MA, Naziruddin B, Poindexter NJ, Haynes AE, Howard T, Mohanakumar T. Liver transplant recipient sera derived soluble HLA mediates allele specific CTL apoptosis. Transplantation. 2000;69(1):157-162.

143. Puppo F, Contini P, Ghio M, Brenci S, Scudeletti M, Filaci G, et al. Soluble human MHC class I molecules induce soluble Fas ligand secretion and trigger apoptosis in activated CD8(+) Fas (CD95)(+) T lymphocytes. Int Immunol. 2000;12(2):195-203.

144. Puppo F, Contini P, Ghio M, Indiveri F. Soluble HLA class I molecules/ CD8 ligation trigger apoptosis of CD8+ cells by Fas/Fas-ligand interaction. Scientific World Journal. 2002;2:421-423.

145. Norment AM, Salter RD, Parham P, Engelhard VH, Littman DR. Cellcell adhesion mediated by CD8 and MHC class I molecules. Nature. 1988;336(6194):79-81

146. Zavazava N, Krönke M. Soluble HLA class I molecules induce apoptosis in alloreactive cytotoxic $\mathrm{T}$ lymphocytes. Nature Med. 1996;2(9):1005-1010.

147. Wilson BS, Indiveri F, Pellegrino MA, Ferrone S. Production and characterization of DR xenoantisera: use for detection of serum DR antigens. J Immunol. 1979;122(5):1967-71.

148. Indiveri F, Wilson BS, Natali PG, Pellegrino MA, Ferrone S. Immunogeneity of DR antigens isolated from body fluids. Transplant Proc. 1980;12(1):121-4.

149. Coupel S, Moreau A, Hamidou M, Horejsi V, Soulillou JP, Charreau B. Expression and release of soluble HLA-E is an immunoregulatory feature of endothelial cell activation. Blood. 2007;109(7):28062814.

150. Herlyn M, Lange B, Bennicelle J. Increased levels of circulating HLA-
DR antigens in sera of patients with acute lymphoblastoid leukemia. Leuk Res. 1984;8(3):323-334.

151. Thompson S, Wareham M, Pearson ADJ, Sviland L, Turner GA. A preliminary study of serum class II levels in healthy individuals and bone marrow transplant patients. Clin Chim Acta. 1989;185(1):4552.

152. Westhoff U, Thinnes FP, Gotz H, Grosee-Wilde H. Quantitation of soluble HLA class II molecules by an enzyme-linked immunosorbent assay. Vox Sang. 1991;61(2):106-110.

153. McDonald JC, Adamashvili I, Hayes JM, Aultman DF, Rhynes VK, Gelder FB. Soluble HLA class II concentrations in normal individuals and transplant recipients. Comparison with soluble HLA class I concentrations. Transplantation. 1994;58(11):12681272.

154. Pouletty P, Ferrone S, Amesland F, Cohen N, Westhoff U, Charron $D$, et al. Summary report from the first international workshop on soluble HLA antigens. Paris, August 1992. Tissue Antigens. 1993;42(1):45-54.

155. Cooper JE, Gralla J, Cagle L, Goldberg R, Chan L, Wiseman AC. Inferior kidney allograft outcomes in patients with de novo donor-specific antibodies are due to acute rejection episodes. Transplantation. 2011;91(10):1103-1109.

156. DeVos JM, Gaber AO, Teeter LD, Graviss EA, Patel SJ, Land GA, et al. Intermediate-term graft loss after renal transplantation is associated with both donor-specific antibody and acute rejection. Transplantation. 2014;97(5):534-540.

157. Vadim J, Ravindranath MH, Terasaki PI. Immunobiology of HLA Class-Ib molecules in transplantation. SOJ Immunology, 2015;3(4).

158. Tongio MM, Falkenrodt A, Mitsuishi Y, et al. Natural HLA Abs. Tissue Antigens, 1985;26(5):271-285. doi: 10.1111/j.1399-0039.1985. tb02225.x.

159. Ameglio F, Saba F, Bitt A, Aceti, N. Tanigaki, R. Sorrentino, A, et al. Antibody reactivity to HLA Classes I and II in sera from patients with hydatidosis. J Infect Dis. 1987;156(4):673-676.

160. Májský A. Natural HLA-A, B and DR Abs in the serum of nonimmunized men. Vnitr Lek. 1989;35(5):467-471.

161. Luscher MA, Choy G, Embree JE, Nagelkerke NJ, Bwayo JJ, Njenga S, et al. Anti-HLA alloantibody is found in children but does not correlate with a lack of HIV type 1 transmission from infected mothers. AIDS Res Hum. Retroviruses. 1988;14(2):99-107.

162. Zhou B, Saito S, Nakazawa Y, Kobayashi N, Matsuda M, Matsumoto $\mathrm{Y}$, et al. Existence of an immunoglobulin G component of naturally occurring HLA class I antibodies that are not directed against selfantigens in human serum. Tissue Antigens. 2008;72(2):98-104. doi: 10.1111/j.1399-0039.2008.01074.x.

163. Lee J, Romero R, Xu Y, Miranda J, Yoo W, Chaemsaithong P. Detection of anti-HLA antibodies in maternal blood in the second trimester to identify patients at risk of antibody-mediated maternal anti-fetal rejection and spontaneous preterm delivery. Am J Reprod Immunol. 2013;70(2):162-75. doi: 10.1111/aji.12141.

164. Ravindranath MH, Terasaki PI, Maehara CY, Jucaud V, Kawakita S, Pham T, et al. Immunoglobulin (Ig)G purified from human sera mirrors intravenous Ig human leucocyte antigen (HLA) reactivity and recognizes one's own HLA types, but may be masked by Fab complementarity-determining region peptide in the native sera. Clin Exp Immunol. 2015;179(2):309-328. doi: 10.1111/cei.12450. 
165. van Rood JJ, van Leeuwen A, van Santen MC. Anti HL-A2 inhibitor in normal human serum. Nature. 1970;226(5243):366-367.

166. Charlton RK, Zmijewski CM. Soluble HL-A7 antigen: localization in the beta-lipoprotein fraction of human serum. Science. 1970;170(3958):636-637.

167. Billing RJ, Mittal KK, Terasaki PI. Isolation of soluble HL-A antigens from normal human sera by ion exchange chromatography. Tissue Antigens. 1973;3(4):251-256.

168. Billing RJ, Terasaki PI. Purification of HL-A antigens from normal serum. J Immunol. 1974;112(3):1124-30

169. Billing R, Terasaki PI. Human leukemia antigen. II. Purification. J Natl Cancer Inst. 1974;53(6):1639-1643.

170. Billing RJ, Terasaki PI. Rabbit antisera to HL-A9 isolated from normal serum. Transplantation. 1974;17(2):231-234.

171. Jucaud V, Ravindranath MH, Terasaki PI. Immunobiology of HLA Class-Ib Molecules in Transplantation. SOJ Immunol. 2015;3(4):115.DOI: dx.doi.org/10.15226/2372-0948/3/4/00137. 